\title{
Modulation of N-Type Calcium Channels in Bullfrog Sympathetic Neurons by Luteinizing Hormone-releasing Hormone: Kinetics and Voltage Dependence
}

\author{
Linda M. Boland and Bruce P. Bean \\ Department of Neurobiology, Harvard Medical School, Boston, Massachusetts 02115
}

\begin{abstract}
Inhlbition of Ca channel current by luteinizing hormone-releasing hormone (LHRH) was studied in freshly dissociated bullfrog sympathetic ganglion neurons using whole-cell recording. LHRH inhibited up to $80 \%$ of the high-threshold $\mathrm{Ca}$ channel current with a half-maximally effective concentration of about $20 \mathrm{~nm}$. LHRH inhibited $\omega$-conotoxin-sensitive but not nimodipine-sensitive current and also did not inhibit Bay $K$ 8644-enhanced currents, suggesting that LHRH inhibits $\mathrm{N}$-type but not L-type channels. Inhibition was faster at higher concentrations of LHRH, reaching a limiting time constant of $2 \mathrm{sec}$ at $\mathbf{0 . 3 - 3} \mathrm{mm}$ LHRH. The rate of recovery from block $(\tau \sim 19 \mathrm{sec})$ was independent of LHRH concentration. Inhibition of N-type current by LHRH was highly sensitive to the gating state of the channel. Though strongly effective if applied when channels were mostly in the resting state, LHRH had little effect if applied rapidly during a long depolarization that opened the channels. Inhibition could be relieved if channels were activated by short, large test depolarizations or by long, smaller depolarizations. The statedependent properties of LHRH block could be simulated by a model that assumes that inhibition by LHRH results from activated G-proteins binding to $\mathrm{N}$-type channels and that (1) G-protein binding stabilizes closed gating states and (2) activation of G-protein-bound channels destabilizes the binding of the G-protein to the channel.
\end{abstract}

[Key words: $\mathrm{Ca}^{2+}$ channel, patch clamp, sympathetic ganglion, luteinizing hormone-releasing hormone, GTP-binding proteins, channel gating]

Many neurotransmitters have been found to inhibit voltagedependent $\mathrm{Ca}^{2+}$ channels in neurons (Anwyl, 1991). In almost all cases, GTP-binding proteins have been implicated in the pathways coupling cell surface receptors to $\mathrm{Ca}$ channels. Inhibition of $\mathrm{Ca}$ current by neurotransmitters is mimicked by and becomes persistent when neurons are dialyzed with GTP $\gamma \mathrm{S}$ ( $\mathrm{Holz}$ et al., 1986; Dolphin and Scott, 1987; Wanke et al., 1987; Ewald et al., 1988; Ikeda and Schofield, 1989; Kasai and Aosaki, 1989; Lipscombe et al., 1989; Song et al., 1989; Toselli and Lux, 1989; Bley and Tsien, 1990; Elmslie et al., 1990; Sah, 1990; Ikeda, 1991; Plummer et al., 1991; Pollo et al., 1991). In some cases, transmitter inhibition of Ca current is prevented or reduced by inactivation of certain G-proteins by pertussis toxin (Holz et al., 1986; Lewis et al., 1986; Wanke et al., 1987; Toselli and

\footnotetext{
Received May 8, 1992; revised July 21, 1992; accepted July 23, 1992.

This work was supported by the NIH (HL35034).

Correspondence should be addressed to Linda M. Boland, Department of Neurobiology, Harvard Medical School, 220 Longwood Avenue, Boston, MA 02115. Copyright (C) 1993 Society for Neuroscience $0270-6474 / 93 / 130516-18 \$ 05.00 / 0$
}

Lux, 1989; Sah, 1990; Ikeda, 1991; Plummer et al., 1991) or G-protein antibodies (Harris-Warwick et al., 1988; McFadzean et al., 1989). Intracellular application of exogenous G-protein subunits can restore transmitter effects in pertussis toxin-treated neurons (Hescheler et al., 1987; Ewald et al., 1988; Toselli et al., 1989).

In addition to reducing $\mathrm{Ca}$ current, neurotransmitters change current kinetics and voltage dependence. Current is inhibited more at small depolarizations than at large depolarizations, and transmitters or GTP $\gamma$ S induce a slow phase of activation (e.g., Lewis et al., 1986; Marchetti et al., 1986; Tsunoo et al., 1986; Green and Cottrell, 1988; Schofield and Ikeda, 1988; Bean, 1989; Kasai and Aosaki, 1989; Elmslie et al., 1990; Pollo et al., 1991). Although these changes offer clues to how channel gating may be altered by transmitters, interpreting them is complicated by the existence in most neurons of multiple types of Ca channels that may be affected differently.

Our goal was to study in more detail how Ca channel behavior is altered by neurotransmitter inhibition. Following the lead of Bley and Tsien (1990) and Elmslie et al. (1990), we have studied inhibition of Ca channel current in bullfrog sympathetic neurons by luteinizing hormone-releasing hormone (LHRH), which they have shown to produce a particularly large and reproducible effect. Bullfrog sympathetic neurons are an advantageous preparation because they have a less complicated mixture of $\mathrm{Ca}$ channel types than many other neurons, with the great majority of current flowing through $\omega$-conotoxin $(\mathrm{CgTx})$-sensitive $\mathrm{N}$-type Ca channels (Jones and Marks, 1989) together with a small component of L-type current (Jones and Jacobs, 1990).

We found that LHRH affects only the N-type Ca channels in these neurons and that there are mutual interactions between transmitter inhibition and channel gating that can be seen in a variety of ways. Many characteristics of the modulation can be simulated by a model that assumes that activated G-proteins bind directly to $\mathrm{N}$-type $\mathrm{Ca}$ channels and thereby alter the voltage dependence of channel gating.

\section{Materials and Methods}

Preparation of freshly dissociated neurons. Paravertebral sympathetic ganglia from adult bullfrog ( $R$ ana catesbiana) were dissected in $\mathrm{a} \mathrm{Ca}^{2+}$ free Ringer's solution consisting of (in mM) $100 \mathrm{NaCl}, 2.5 \mathrm{KCl}, 5 \mathrm{MgCl}_{2}$ 10 glucose, and 10 HEPES, $\mathrm{pH}$ 7.4. Ganglia were cut in half, and tissue pieces were incubated at $31-34^{\circ} \mathrm{C}$ with $1 \mathrm{mg} / \mathrm{ml}$ collagenase (type $\mathrm{I}$, Sigma) plus $5 \mathrm{mg} / \mathrm{ml}$ dispase (Bochringer Mannheim Biochemicals, Indianapolis, IN) in the $\mathrm{Ca}^{2+}$-free Ringer's solution. After $\mathrm{l} \mathrm{hr}$, the enzyme solution was replaced with a fresh $\mathrm{Ca}^{2+}$-free Ringer's solution containing $5 \mathrm{mg} / \mathrm{ml}$ dispase, and incubation at $31-34^{\circ} \mathrm{C}$ for an additional hour was followed by trituration with a fire-polished Pasteur pipette to yield single cells. The mixture was then diluted twofold with $\mathrm{Ca}^{2+}$-free Ringer's solution and stored at $4^{\circ} \mathrm{C}$ until use, generally within $48 \mathrm{hr}$. In a few 
experiments, young bullfrogs were used with similar results, except that desensitization was often slower.

Voltage clamp. Recordings were made from freshly dissociated cell bodies to avoid artifacts associated with inadequate voltage clamp of neuronal processes. We did not distinguish between large (B-type) and small (C-type) sympathetic neurons; LHRH seemed equally effective on neurons of all sizes. Macroscopic currents through voltage-dependent $\mathrm{Ca}^{2+}$ channels were recorded using the whole-cell patch-clamp configuration (Hamill et al., 1981). Patch pipettes were made from borosilicate glass tubing (Boralex, Rochester Scientific Co., Rochester, NY), coated with Sylgard (Dow Corning Corp.), and fire polished. Pipettes had resistances of 1-3 M $\Omega$ when filled with internal solution (below). Currents were measured with a List EPC-7 amplifier (Medical Systems Corp., Greenvale, NY), filtered with the $10 \mathrm{kHz}$ four-pole Bessel filter built into the amplifier, digitized at 20-200 msec intervals, and stored on a computer. Leak and capacitative currents were subtracted using scaled current for a 10 or $20 \mathrm{mV}$ hyperpolarizing pulse. Experiments were done at room temperature $\left(19-24^{\circ} \mathrm{C}\right)$.

Series resistances ranged from 0.2 to $2.0 \mathrm{M} \Omega$ after partial compensation (typically 70 to $>90 \%$ ); only data from cells with low series resistance and currents small enough to maintain a voltage error of less than $5 \mathrm{mV}$ were analyzed. All potentials were corrected for a liquid junction potential of $-10 \mathrm{mV}$ between the internal solution and the Tyrode's solution in which pipette current was zeroed. The membrane holding potential was $-90 \mathrm{mV}$ except where noted.

Solutions. The standard internal solution consisted of (in mM) 108 Cs-glutamate, 9 HEPES, 9 EGTA, and $4.5 \mathrm{MgCl}_{2}$, pH 7.4, with CsOH, plus an ATP-regenerating solution (Forscher and Oxford, 1985) that slows rundown of $\mathrm{Ca}^{2+}$ channel current in these cells. Final concentrations of these ingredients were (in mM) 14 creatine phosphate (Tris salt, Sigma), 4 Mg-ATP (Sigma), and 0.3 GTP (Tris salt; Boehringer Mannheim or Sigma), pH 7.4 with Tris basc.

Seals between electrodes and cells were established in a modified Tyrode's solution consisting of (in mM) $150 \mathrm{NaCl}, 4 \mathrm{KCl}, 4 \mathrm{BaCl}_{2}, 2$ $\mathrm{CaCl}_{2}, 2 \mathrm{MgCl}_{2}, 10$ glucose, and 10 HEPES, pH 7.4 with $\mathrm{NaOH}$. Immediately after establishing the whole-cell configuration, cells were lifted on the end of the electrode and placed in front of a gravity-fed stream of solution flowing out of one of several microcapillary tubes $(1 \mu \mathrm{l}$ "microcaps," Drummond Scientific) glued together side by side (Friel and Bean, 1988). Cells were moved into a stream of solution to achieve moderately rapid exchange of the solution surrounding the cell; complete exchange occurred within $80-160 \mathrm{msec}$, as determined from the time necessary to alter current amplitude when moving between solutions with different divalent concentrations. The external solution consisted of (in mM) $2 \mathrm{BaCl}_{2}, 160$ tetraethylammonium (TEA) Cl, $10 \mathrm{HEPES}, 0.1$ EGTA, and $1 \mathrm{mg} / \mathrm{ml}$ cytochrome $\mathrm{C}$ (to minimize binding of peptides to plastic containers and tubing), $\mathrm{pH} 7.4$ with TEA-OH and, in some experiments, $3 \mu_{\mathrm{M}} \mathrm{TTX}$.

$\omega$-Conotoxin fraction GVIA (CgTx), LHRH (chicken type II), and other LHRH analogs were purchased from Peninsula Peptides (Belmont, CA). TTX was purchased from Sigma. Stock solutions of nimodipine and BAY K 8644 (kind gifts of Dr. Alexander Scriabine, Miles Laboratories, New Haven, CT) were prepared in polyethylene glycol or dimethyl sulfoxide and were stored in the dark at $4^{\circ} \mathrm{C}$.

All data are presented as mean \pm SEM.

Modeling. The occupancy of different states of the models was calculated using Runge-Kutta integration with a time step of $20 \mu \mathrm{sec}$. The rate constants that are exponential functions of voltage were "clipped" at $100 \mathrm{msec}^{-1}$ to avoid integration errors; none of the presented results were affected. To generate simulatcd currents, it was assumcd that there were 10,000 channels; single-channel current was calculated from the constant-field current equations with permeability to $\mathrm{Ba}(2 \mathrm{~mm}$ external $)$ and $\mathrm{Cs}$ ( $165 \mathrm{~mm}$ internal). The single-channel permeability to $\mathrm{Ba}$ was $3 \times 10^{-7} \mathrm{~cm} / \mathrm{sec}$, and $P_{\mathrm{Cs}}$ was 50 times lower; the upward concavity of outward current seen experimentally was approximated by multiplying $P_{\mathrm{Cs}}$ by $1 /(1+103 * \exp (-2 V F / R T))$, where $V$ is voltage and $F, R$, and $T$ have their usual meanings, as if flow of Cs is impeded by a blocking particle of valence 2 .

\section{Results}

\section{LHRH inhibits a fraction of the Ca channel current}

As reported by Bley and Tsien (1990) and Elmslie et al. (1990), LHRH (chicken type II) inhibited a large fraction of the highthreshold Ba current (Fig. 1A). The inhibition by LHRH was
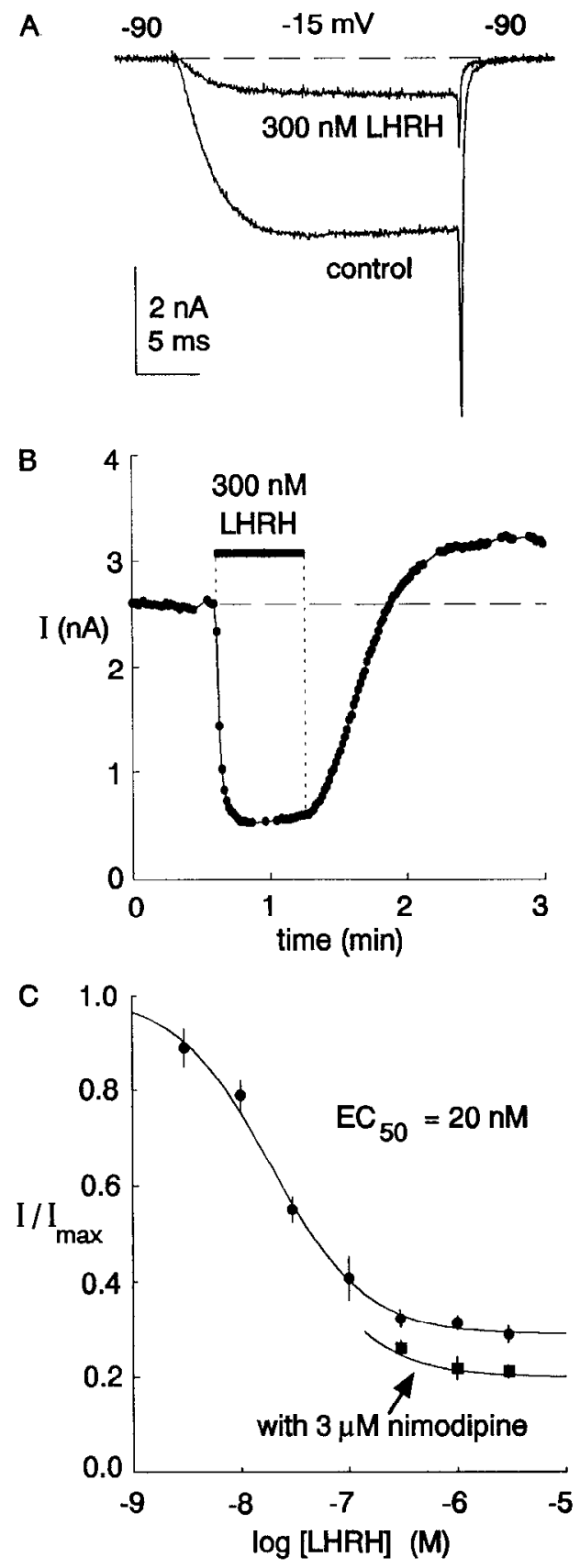

Figure 1. Inhibition by LHRH (chicken type II) of Ba current in a bullfrog sympathetic ganglion neuron. $A$, Currents in the absence and presence of $300 \mathrm{~nm} \mathrm{LHRH.} B$, Plot of peak current versus time for a different cell; $10 \mathrm{msec}$ depolarizations from $-90 \mathrm{mV}$ to $-20 \mathrm{mV}$ were delivered once per second with occasional interruptions to assay leak current (using a step to $-100 \mathrm{mV}$ ). Ba current was measured as average current between 7 and $9 \mathrm{msec}$, roughly the time of peak current in control, after leak correction. $C$, Concentration dependence of LHRH inhibition of Ba current. Inhibition was measured in the absence (circles) or presence (squares) of $3 \mu \mathrm{M}$ nimodipine. Measurements were made at test potentials that maximized inward current $(-20$ to $-10 \mathrm{mV})$. Symbols represent means \pm SEM for 3-17 (no nimodipine) or 4-25 (with nimodipine) determinations. Cells were exposed to up to four different concentrations of LHRH. The smooth curve is fit according to $I / I_{\max }=0.29 /\left(0.71+\left([\mathrm{LHRH}] / \mathrm{EC}_{50}\right)\right)$ with an $\mathrm{EC}_{50}$ of $20 \mathrm{nM}$. In the presence of nimodipine, the curve is fit with the same $\mathrm{EC}_{50}$ but with $78 \%$ maximum inhibition. 


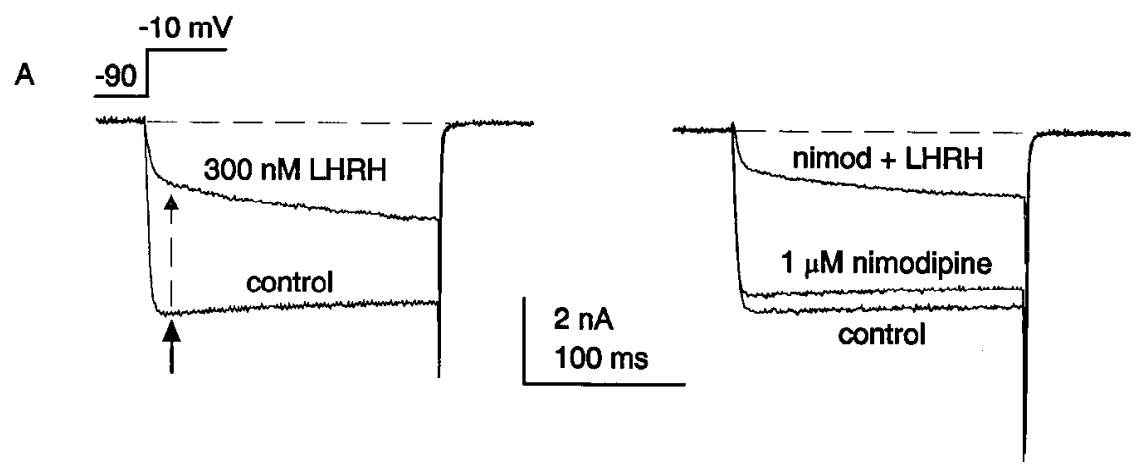

Figure 2. Effect of LHRH on L-type current. $A$, Modulation by $300 \mathrm{nM}$ LHRH before (left; $67 \%$ inhibition) and after (right; $75 \%$ inhibition) application of $1 \quad \mu_{\mathrm{M}}$ nimodipine; nimodipine blocked $9 \%$ of the current in this cell. For this and subsequent figures, depolarization-activated currents were measured at the time the control inward current reached a peak, denoted here by the arrows. $B$, LHRH cffcct on tail current enhanced by $1 \mu \mathrm{M}$ Bay K 8644 . LHRH (300 nM) was applied in the constant presence of Bay $\mathrm{K}$ (thick line). $C$, Effect of 300 nM LHRH on L-type current enhanced by $1 \mu \mathrm{M}$ Bay K 8644 in the presence of $3 \mu \mathrm{M} C g T x$.
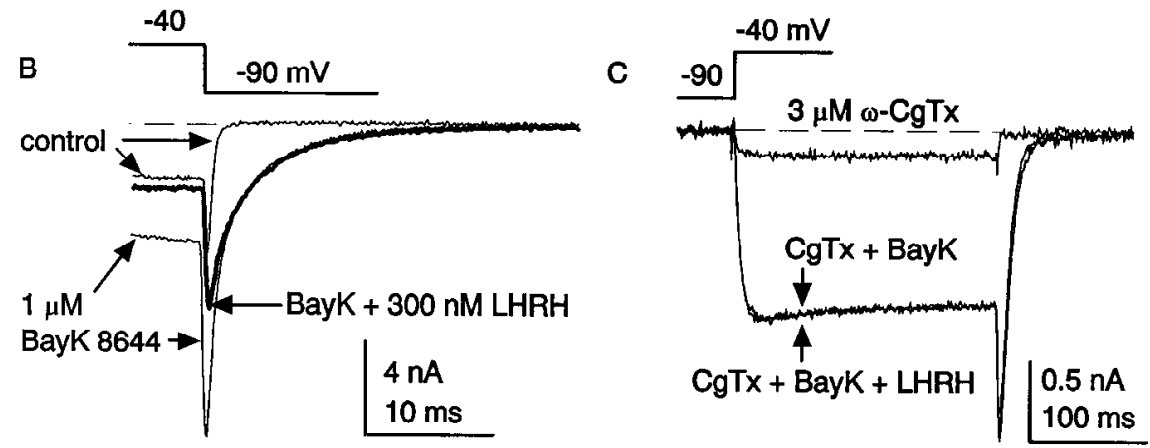

reliable (present in 170 of 177 cells tested) and large, inhibiting $78 \pm 1 \%$ of the $\mathrm{N}$-type current at saturating concentrations ( $n$ $=70$ ). The inhibition by LHRH was completely reversible. In fact, in about half the cells tested, current actually recovered to a value larger than control following the first application of LHRH (Fig. 1 $B$ ); similar "overrecovery" has previously been reported for LHRH inhibition of both M-type $\mathrm{K}^{+}$current (Pfaffinger, 1988; Bosma and Hille, 1989) and Ca channel current (Bley and Tsien, 1990) in these cells. In most cases, we confined studies on how channel behavior was altered by LHRH to applications where there was no overrecovery.

Although most experiments were done using $\mathrm{Ba}$ as charge carrier, similarly large and reproducible effects were seen using $\mathrm{Ca}$ as charge carrier; $0.1-1 \mu \mathrm{M}$ LHRH inhibited $87 \pm 4 \%$ of peak inward current in six of six cells tested in $2 \mathrm{mM} \mathrm{Ca}^{2+}$ plus $3 \mu \mathrm{M}$ nimodipine.

Although LHRH is among the most efficacious transmitters that inhibit Ca channel current in these (Bley and Tsien, 1990) or other neurons, saturating concentrations of LHRH (0.3-3 $\mu \mathrm{M})$ produced incomplete inhibition of the peak inward current. Figure $1 C$ illustrates the LHRH concentration-response relationship for the inhibition of Ba current. The effect on the $\mathrm{Ba}$ current elicited at -20 to $-10 \mathrm{mV}$ was measured at the time the control current reached a peak (see Fig. $2 A$, arrows). In experiments done in the absence of nimodipine (Fig. $1 C$, circles), the smooth curve is fit to the concentration-response data according to $I / I_{\max }=0.29+0.71 /\left(1+\left([\mathrm{LHRH}] / \mathrm{EC}_{50}\right)\right)$, with $\mathrm{EC}_{50}$ $=20 \mathrm{nM}$. In the presence of $3 \mu \mathrm{M}$ nimodipine (Fig. $1 \mathrm{C}$, squares), the maximal inhibition was increased from $71 \%$ to $78 \%$, reflecting the removal of the LHRH-insensitive L-type Ca channel population (see below).

Other LHRH analogs did not inhibit the Ba current when tested at $1 \mu \mathrm{M}$ on cells that demonstrated inhibition by chicken type II LHRH. These analogs included chicken type I LHRH (Gln ${ }^{8}$-LHRH), human LHRH, and salmon LHRH $(n=5-8)$.
In addition, the analogs [D-Phe ${ }^{2}$, Pro $\left.^{3}, \mathrm{D}-\mathrm{Phe}^{6}\right]-\mathrm{LHRH}$ and [DpGlu',D-Phe $\left.{ }^{2}, \mathrm{D}-\mathrm{Trp}^{3,6}\right]-\mathrm{LHRH}$, which act as competitive antagonists in some systems (Humphries et al., 1978; King et al., 1988), were not effective antagonists (when tested at 1-10 $\mu \mathrm{M}$ ) of the effects of $300 \mathrm{nM}$ or $1 \mu \mathrm{M}$ LHRH $(n=3-4)$.

With prolonged ( $>1 \mathrm{~min}$ ) applications of high concentrations ( $>100 \mathrm{nM}$ ) of LHRH, its effect on current size gradually faded or desensitized. The rate of desensitization was faster in higher concentrations of LHRH. The time of onset and the rate of desensitization varied in different cell preparations; in some preparations using neurons isolated from young bullfrogs, there was no desensitization of current inhibition even when $1 \mu \mathrm{M}$ LHRH was applied for $2 \mathrm{~min}$. In most further expcriments, the effects of LHRH were studied during the $1-2$ min period before desensitization began.

\section{Pharmacological characterization of the modulated channels}

Previous work has shown that only $5-15 \%$ of the Ca channel current in bullfrog sympathetic neurons is contributed by dihydropyridine-sensitive L-type channels (Jones and Marks, 1989; Lipscombe et al., 1989; Bley and Tsien, 1990; Jones and Jacobs, 1990). Consistent with these reports, we found that nimodipine (1-3 $\mu \mathrm{M}$ ) blocked only $9 \pm 1 \%$ of the whole-cell current $(n=$ 17). In the presence of $3 \mu \mathrm{M}$ nimodipine, $3 \mu \mathrm{M}$ CgTx blocked $97 \pm 1 \%$ of the remaining current $(n=16)$. Thus, about $90 \%$ of the high-threshold current is contributed by N-type Ca channels sensitive to CgTx (Jones and Marks, 1989).

We tested whether L-type channels in these cells are affected by LHRH. Figure $2 A$ shows that LHRH inhibition was equally effective in the absence or presence of nimodipine $(n=6)$. We also tested whether L-type current enhanced by the dihydropyridine agonist Bay K 8644 could be modulated by LHRH. Bay K 8644 and other dihydropyridine "agonists" greatly slow deactivation of L-type channels (Hess et al., 1984; Nowycky et al., 1985), inducing a distinction between tail currents carried 


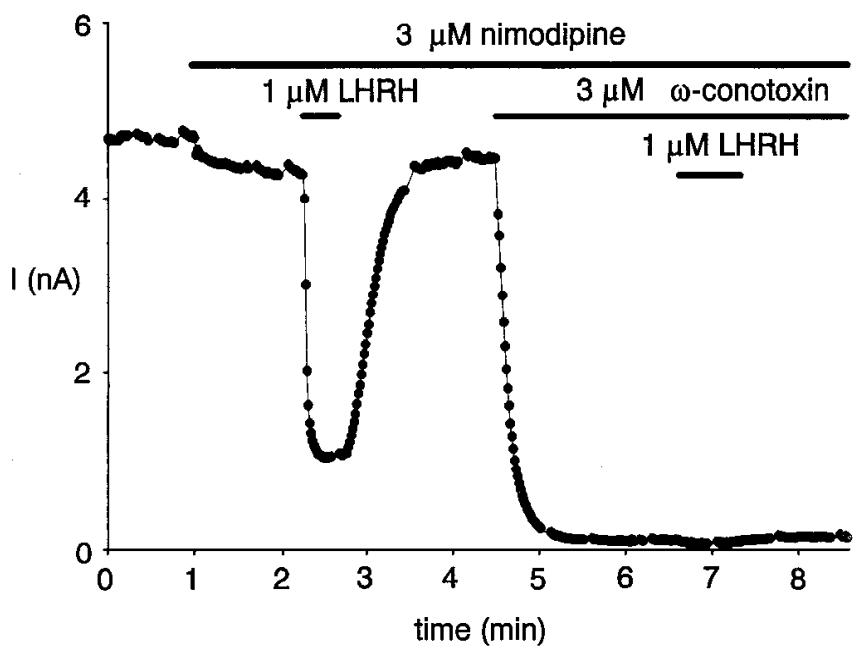

Figure 3. Effect of $\omega$-conotoxin on inhibition by LHRH. Currents were elicited by depolarizations from $-90 \mathrm{mV}$ to $-20 \mathrm{mV}$ once per second with occasional interruptions to assay the leak current at $-100 \mathrm{mV}$.

through L-type and N-type channels (Plummer et al., 1989; Bley and Tsien, 1990), which in the absence of drug have very similar time constants (Regan et al., 1991). LHRH had no effect on the slow tail current induced by Bay K 8644, while inhibiting both a fraction of the depolarization-activated current and a fast component of tail current (Fig. $2 B$ ); this experiment was repeated with identical results in three other cells. LHRH also had no effect on the current activated by a depolarization to $-40 \mathrm{mV}$ after N-type current was blocked by $\mathrm{CgTx}$ and the remaining L-type current was enhanced by Bay K 8644 (Fig. $2 C ; n=5$ ) even though these same cells each showed strong inhibition by $\mathrm{LHRH}$ prior to $\mathrm{CgTx}$ exposure. It is clear that Bay $\mathrm{K} 8644$ does not interfere with the actions of LHRH on the Ba current because cells not exposed to $\mathrm{CgTx}$ but treated with Bay K 8644 displayed typical LHRH inhibition of the test pulse current and fast tail current (Fig. $2 B$ ). Thus, the evidence seems convincing that current through L-type Ca channels in bullfrog sympathetic neurons is not inhibited by LHRH.

In the presence of $3 \mu \mathrm{M}$ nimodipine to block L-type channels, $3 \mu \mathrm{M}$ CgTx blocked nearly all the remaining Ba current in these cells, demonstrating that both the current inhibited by LHRH and the $15-30 \%$ current fraction remaining in LHRH are carried by $\mathrm{N}$-type channels (Fig. 3). In some cells, a very small current (on average, about $3 \%$ of the initial current) remained after block by the combination of saturating concentrations of nimodipine and $\mathrm{CgTx}$. This may suggest the existence of a very small population of $\mathrm{CgTx}$-resistant channels that are sensitive to LHRH inhibition, although it is hard to rule out incomplete block by $\mathrm{CgTx}$ of a homogeneous population of N-type channels.

Most further experiments were designed to examine how LHRH modified the kinetics and voltage dependence of $\mathrm{Ca}$ channels. Since L-type channels were not modulated by LHRH, recordings were done in the presence of $3 \mu \mathrm{M}$ nimodipine with the hope of assaying a relatively homogeneous population of CgTx-sensitive N-type Ca channels.

\section{Kinetics of LHRH inhibition and recovery}

Figure 4 compares the time course of inhibition and recovery from inhibition by different concentrations of LHRH. The development of inhibition could be fit well by a single exponential and was concentration dependent, reaching a limiting time constant of about $2 \mathrm{sec}$ at high concentrations of LHRH (Fig. 4B). The recovery from inhibition was roughly exponential after an initial lag and was independent of LHRH concentration, with
A
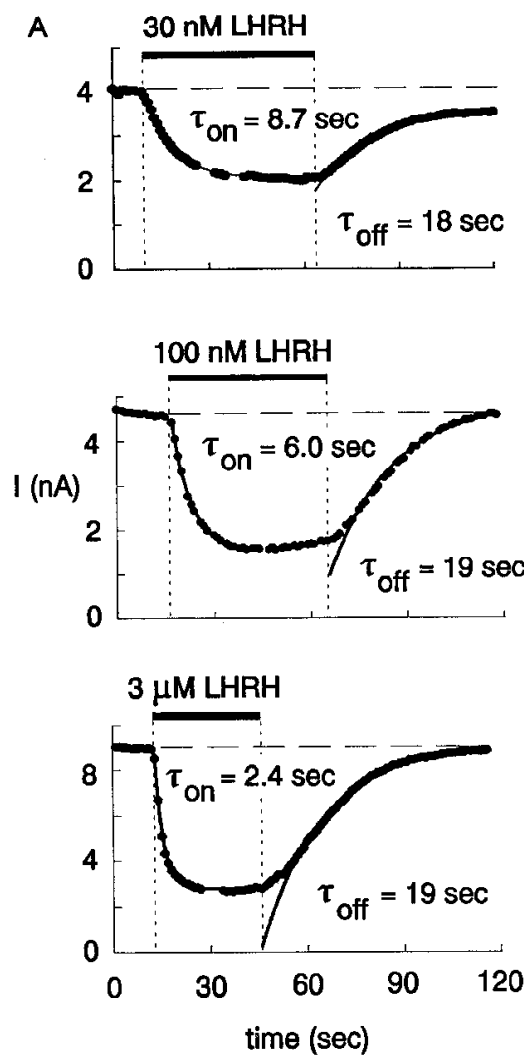

B

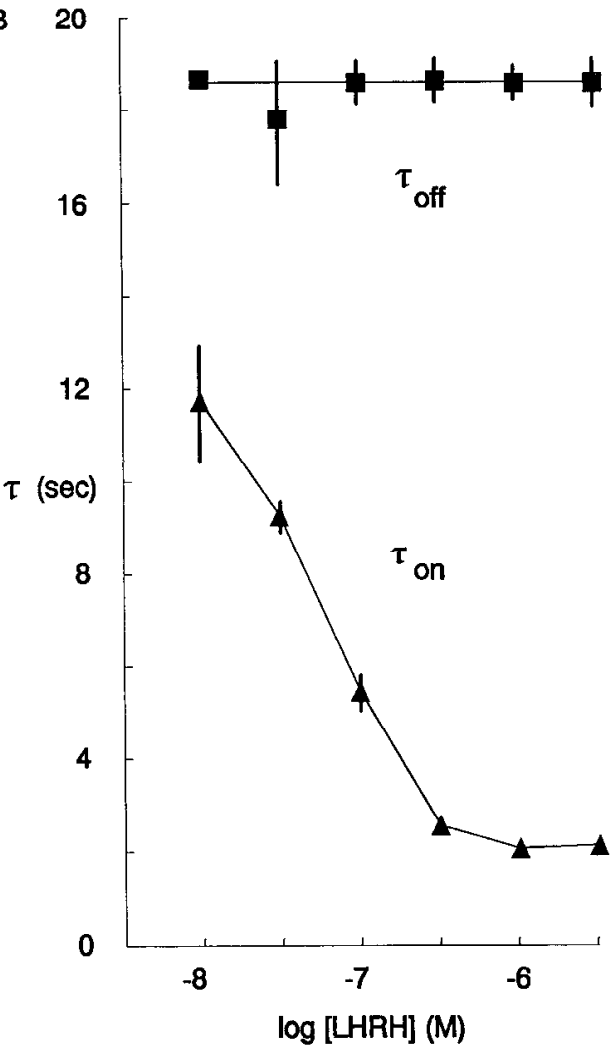

Figure 4. Kinetics of LHRH inhibition and recovery. $A$, Concentration dependence of inhibition and recovery in three different cells. Solid lines are single exponentials fit to the data. $B$, Average time constants for inhibition and recovery. Symbols represent the means \pm SEM for 3-24 determinations except for the data point for $\tau_{\text {off }}$ at $10 \mathrm{nM} \mathrm{LHRH}$, which represents a single determination. Cells were exposed to up to four concentrations of LHRH. All recordings with $3 \mu \mathrm{M}$ nimodipine. 
Figure 5. Effect of LHRH on currents elicited by small or large test depolarizations. $A$, N-type $\mathrm{Ca}$ channel current elicited by steps from $-90 \mathrm{mV}$ to -10 $\mathrm{mV}$ or $+140 \mathrm{mV}$ in the absence or presence of $1 \mu \mathrm{M}$ LHRH. $B$, Current-voltage relationship for the effect of $\mathrm{LHRH}$ on peak Ba current (as in Fig. $2 A$ ). All recordings were in the presence of $3 \mu \mathrm{M}$ nimodipine, and small outward currents remaining after block by $600 \mu \mathrm{M}$ $\mathrm{Cd}^{2+}$ were subtracted from each record.
A
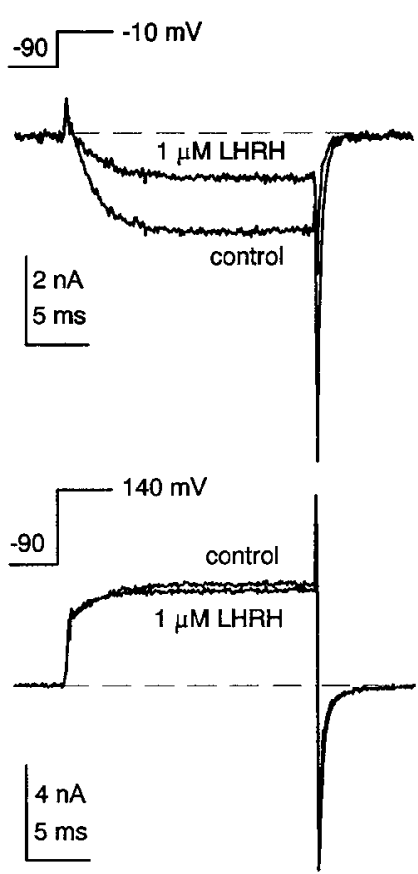

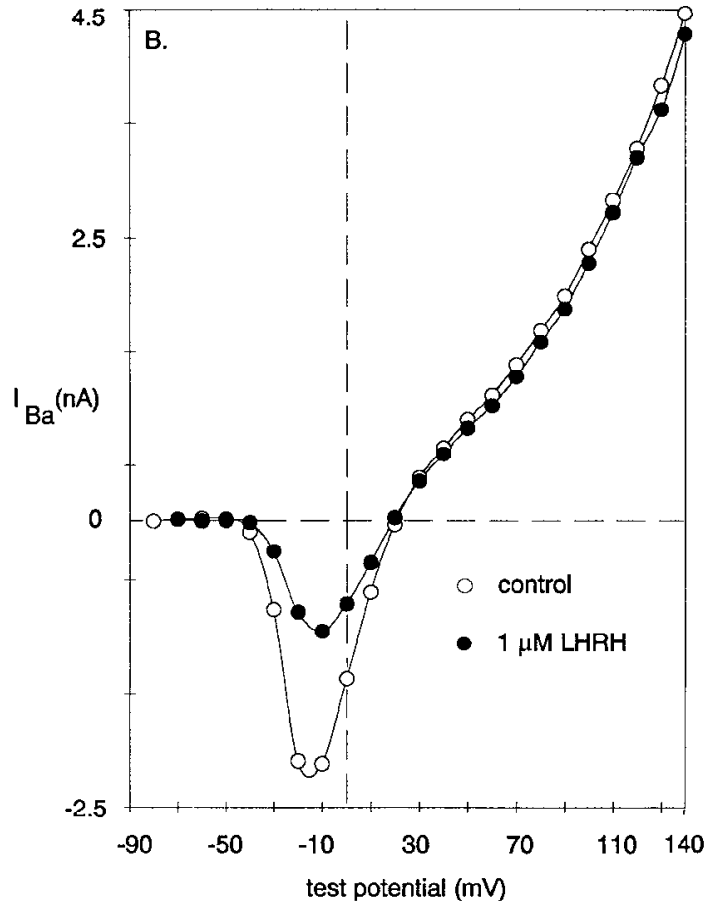

an average time constant of about $19 \mathrm{sec}$ (Fig. $4 \mathrm{~B}$ ). Although the main phase of recovery was the same after exposure to different concentrations of LHRH, the lag in recovery before the exponential phase was shorter with lower concentrations and longer with higher concentrations (Fig. $4 A$ ).

Consistent with previous reports (Bley and Tsien, 1990; Elmslie et al., 1990), we found that replacement of GTP in the internal solution with the nonhydrolyzable GTP analog guanosine-5'$O$-(3-thiotriphosphate) $(\mathrm{GTP} \gamma \mathrm{S})$ made LHRH inhibition persistent $(n=5)$.

\section{Voltage dependence of LHRH inhibition}

With $\mathrm{Cs}^{+}$as the predominant internal cation, depolarizationactivated current reversed direction at about $+40 \mathrm{mV}$ (Fig. 5). The outward current positive to $+40 \mathrm{mV}$ was carried by primarily by $\mathrm{Cs}^{+}$ions flowing through Ca channels, since in cells with small leak conductance the outward current could be blocked completely by $\mathrm{Gd}^{3+}, \mathrm{Cd}^{2+}$, or $\mathrm{CgTx}$. The outward Ca channel current was absent if TEA replaced internal Cs. (In cells with larger leak currents, the apparent reversal potential was often more negative, between +20 and $+40 \mathrm{mV}$, and at more positive potentials small non- $\mathrm{Ca}$ channel outward currents remained after leak correction.)

LHRH usually inhibited Ca channel current at all voltages, but inhibition was much greater for small or moderate depolarizations than for large depolarizations. In 15 cells, peak inward current elicited by steps to -20 or $-10 \mathrm{mV}$ was inhibited by $72 \pm 3 \%$ of control, while outward current at +130 to +150 $\mathrm{mV}$ was inhibited by only $11 \pm 3 \%$. LHRH had no effect on the reversal potential.

The voltage dependence of inhibition by $\mathrm{LHRH}$ was also evident by comparing the relative tail current amplitudes measured after activating pulses to -30 or $+140 \mathrm{mV}$ (Fig. $6 \mathrm{D}$ ). Tail currents following pulses to $-30 \mathrm{mV}$ were inhibited by $70 \pm$ $3 \%$ of control, but with maximal channel activation following pulses to $+140 \mathrm{mV}$, inhibition was much less, by only $28 \pm$
$3 \%(n=14)$. The reason for the discrepancy between inhibition of outward current (11\%) and tail current following the outward current $(28 \%)$ is not obvious, since the outward currents were measured after subtraction of Cd-insensitive currents. The measurements using tail currents may provide a more accurate estimate of inhibition at very depolarized potentials because there is no problem with contamination by non-Ca channel currents, which may be imperfectly corrected for by Cd block.

The voltage dependence of LHRH inhibition of N-type current was examined in more detail using tail currents to assay the extent of channel activation during test pulses to different voltages (Fig. 6). In most cases, tail currents were measured at relatively depolarized potentials $(-40$ to $-20 \mathrm{mV})$ to reduce and slow the currents (e.g., Fig. 6A,B). We rejected data from cells showing more than $10 \%$ desensitization during the protocol, and since we were especially interested in the effect of LHRH at the most positive potentials, we ran some activation protocols from $+140 \mathrm{mV}$ in the negative direction as well some from $-80 \mathrm{mV}$ in the positive direction. Activation curves were not different with the two procedures, and the data were combined for analysis.

Using 15-30 msec test pulses to activate the Ca channels, the activation curve defined by tail currents under control conditions could usually be fit fairly well by a single Boltzmann function but with a small deviation at potentials positive to $0 \mathrm{mV}$, where the experimental values continue to increase slightly while the fitted function saturates. In the presence of $\mathrm{LHRH}$, tail currents following small or moderate depolarizations (Fig. 6A) were decreased much more than those following very large depolarizations (Fig. $6 \mathrm{~B}$ ) and the fit by a single Boltzmann function was grossly inadequate. For both control and LHRH data, activation curves were better fit by the sum of two Boltzmann functions (Fig. 6C). We found that the control and LHRHmodulated activation curves could be fit well by a sum of the same two Boltzmann functions, with different relative amplitudes of the two components. In 14 determinations, the first 
A

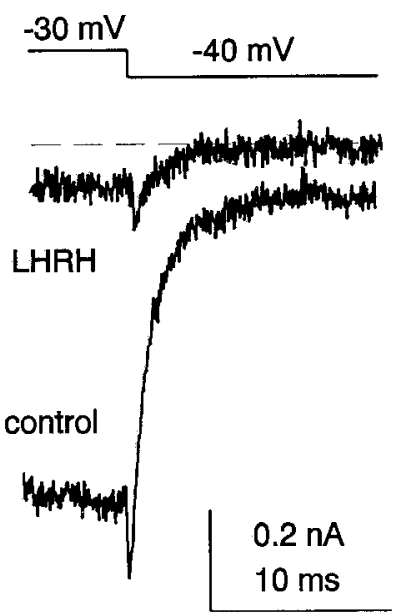

B

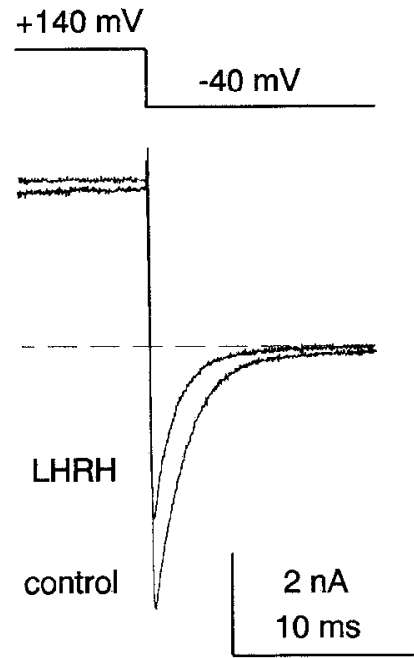

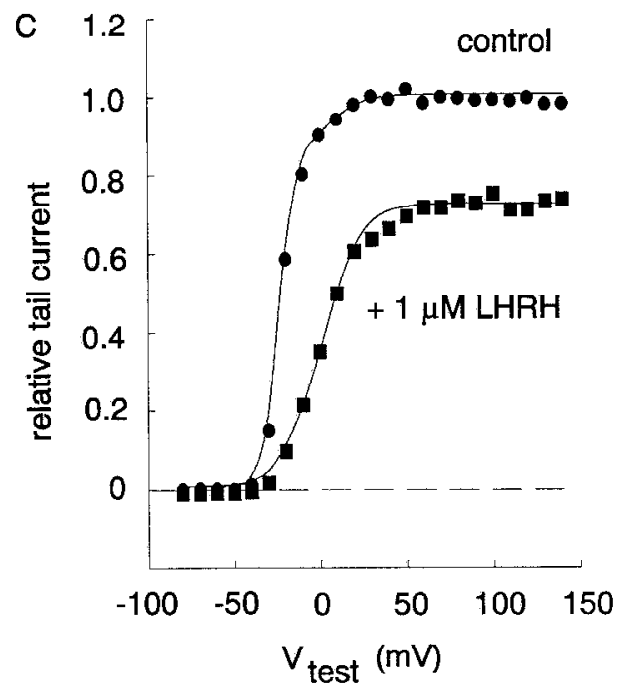

D. 100

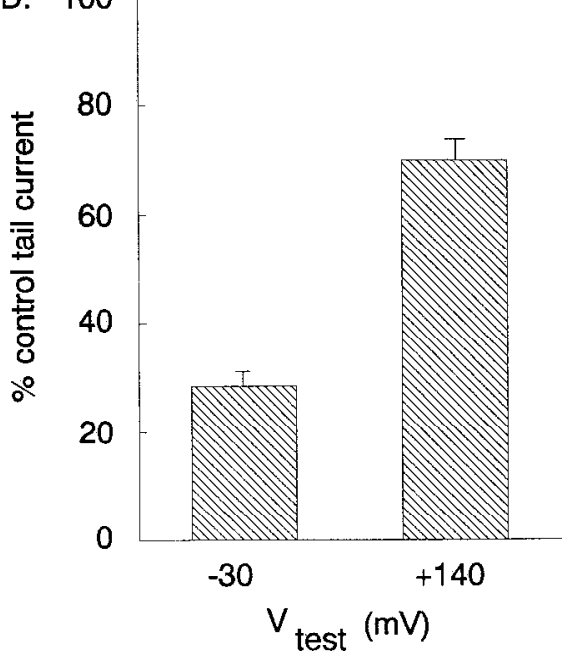

Figure 6. Effect of LHRH on the amplitude of tail currents: tail currents elicited at $-40 \mathrm{mV}$ following test depolarizations from $-90 \mathrm{mV}$ to $-30(A)$ or $+140 \mathrm{mV}(B)$ for control currents and those inhibited by LHRH in the same cell. $C$, Tail current activation curves for $\mathrm{N}$-type current in the absence or presence of $1 \mu \mathrm{M}$ LHRH. 'Tail currents were measured as the current averaged over $160 \mu \mathrm{sec}$ beginning $200 \mu \mathrm{sec}$ after the time of repolarization, normalized to the maximal tail current in control. The two activation curves were simultaneously fit by the sum of the same two Boltzmann functions with different relative contributions in the two cases. The first component had a midpoint of $-24 \mathrm{mV}$ and a slope factor of $4.5 \mathrm{mV}$, and the second component had a midpoint of $+2.6 \mathrm{mV}$ and a slope factor of $11 \mathrm{mV}$. Under control conditions, the component with a midpoint of $-24 \mathrm{mV}$ comprised $82 \%$ of the total whereas in LHRH, this component was $7 \%$ of the total. The fitting was done by simultaneously fitting both sets of data, varying the two midpoints, slope factors, and relative contributions of the Boltzmann components in order to minimize the sum of squares of differences between experimental data and fitted curves. $D$, Relative amplitude of the tail current following test depolarizations to -30 or $+140 \mathrm{mV}$ (mean \pm SEM, $n=14$ cells; $300 \mathrm{nM}$ to $1 \mu \mathrm{M}$ LHRH). All recordings were made with $3 \mu \mathrm{M}$ nimodipine. component had a midpoint of $-24 \pm 2 \mathrm{mV}$ and a slope factor of $4.6 \pm 0.3 \mathrm{mV}$ and the second component had a midpoint of $+1 \pm 3 \mathrm{mV}$ and a slope factor of $12 \pm 1.0 \mathrm{mV}$. Under control conditions, the amplitude of the first current component was $85 \pm 2 \%$. In contrast, in the presence of LHRH $(0.3-1 \mu \mathrm{M} ; n$ $=14$ ), the relative amplitude of the first component was $29 \pm$ $5 \%$. Thus, in the presence of LHRH a large fraction of the current shows a depolarizing shift of about $25 \mathrm{mV}$. Similar results were obtained in three additional cells in which GTP $\gamma \mathrm{S}$ replaced GTP in the internal solution.

Although this analysis is consistent with the idea that LHRH shifts the equilibrium between two modes of gating that coexist even in control conditions (with about $15 \%$ of the channels in the less-easily-opened mode), the curve fitting is not precise enough to favor this picture over many alternatives; the more positive Boltzmann function had such a small amplitude in control that the fit with a wide variety of midpoints and slopes would be little different, and control activation curves were fit reasonably well even with no second component.

\section{Tail current kinetics}

The kinetics of tail currents were altered by LHRH, with the degree of change strongly dependent on the pulse protocol used to activate the channels. Figure 7 illustrates the effect of LHRH on tail currents elicited in the same cell using two different protocols. With a $15 \mathrm{msec}$ depolarization to $-10 \mathrm{mV}$, LHRH reduced the current to about $35 \%$ of its control level (Fig. $7 A$ ). With moderate depolarizations such as this, LHRH consistently produced a slight but detectable speeding of tail current deactivation, as made evident by scaling the tail in LHRH to match the peak size of the control (Fig. 7 $A$, right). With such a protocol, the tail time constant was typically $10-20 \%$ shorter in LHRH.

The spccding of the tail current was much more dramatic if the current was elicited by a short, strong depolarization, as in Figure $7 B$, where current was activated by a $1 \mathrm{msec}$ step to $+130 \mathrm{mV}$. Although LHRH has a smaller effect on current size with this protocol, it has a larger effect on tail current kinetics, reducing the time constant of the tail by about $40 \%$. With large depolarizations, the change in tail current kinetics was largest with short steps, as in Figure $7 B$; in the presence of LHRH (but not in control), the time course of the tail was strongly dependent on the duration of activating pulse, becoming slower with longer depolarizations (this effect can be seen in Fig. $11 \mathrm{~A}$ ).

\section{LHRH induces a slow phase of activation of $N$-type current}

Figure $8 A$ illustrates the effect of LHRH on N-type current elicited by $200 \mathrm{msec}$ pulses to different test potentials. The voltage dependence of LHRH inhibition is manifested in two 

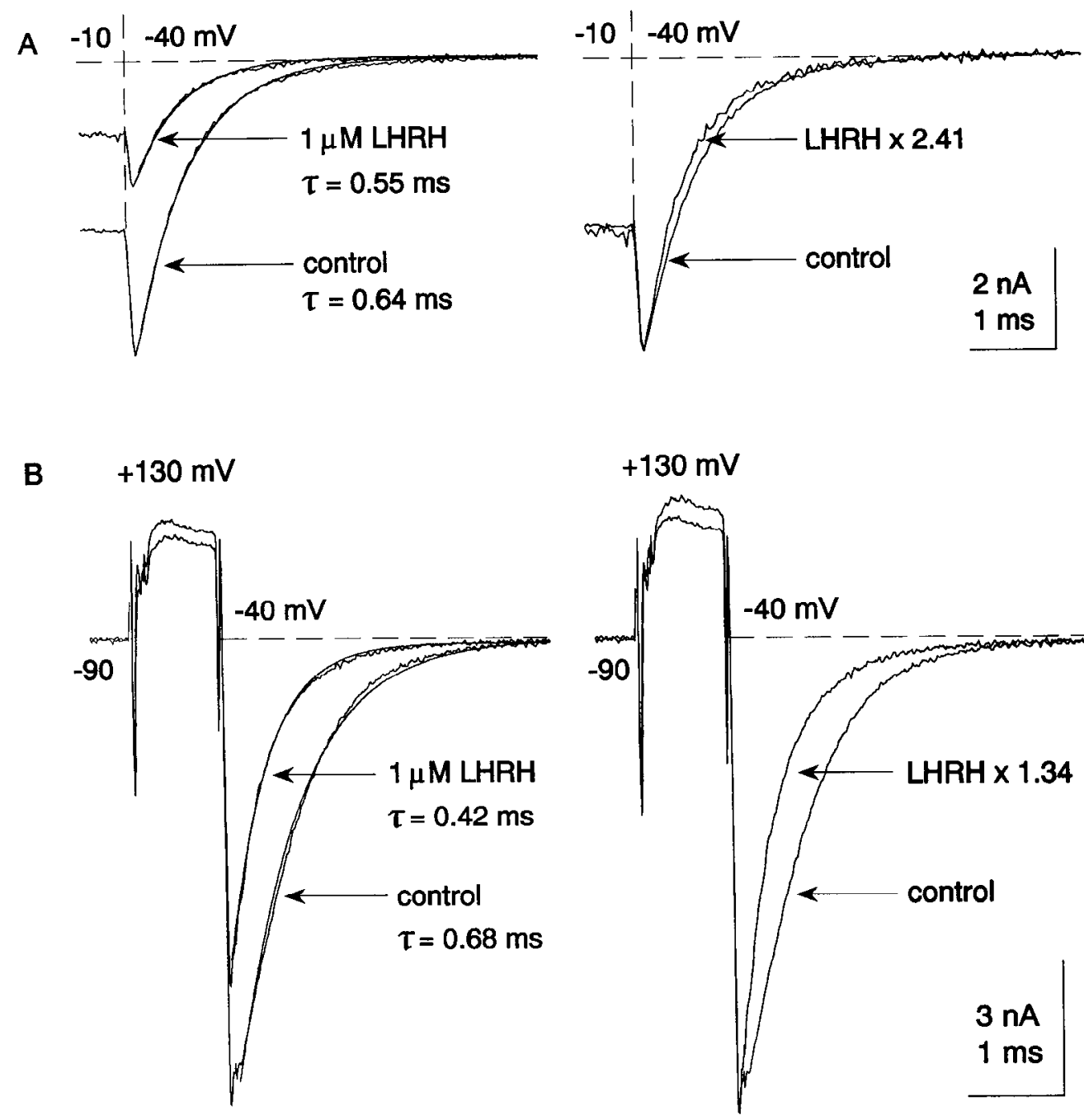

Figure 7. Effect of LHRH on deactivation of $\mathrm{N}$-type $\mathrm{Ca}$ channel current: tail currents at $-40 \mathrm{mV}$ in the absence or presence of $1 \mu \mathrm{M} L H R H$ following $15 \mathrm{msec}$ test pulses to $-10 \mathrm{mV}(A)$ or $1 \mathrm{msec}$ test pulses to $+130 \mathrm{mV}(B)$. Traces on the left are fit with single exponentials. On the right, records obtained in the presence of LHRH are scaled up to match the control peak tail current amplitude. All recordings were made with $3 \mu_{\mathrm{M}}$ nimodipine. Cell capacitance was $23 \mathrm{pF}$; uncompensated series resistance was $2.0 \mathrm{M} \Omega$, of which $80 \%$ was compensated.

ways. First, as expected from the results in Figures 5-7 with short depolarizations, the degree of inhibition early in the pulse becomes less with stronger depolarizations. Second, with LHRH there is a slow phase of activation, so that there is less inhibition late in the depolarization, and this slow phase of activation becomes progressively faster with increasing depolarization. At lower depolarizations, the slow phase of activation continued for hundreds of milliseconds (as in the $800 \mathrm{msec}$ depolarization shown in Fig. $8 B$ ), while above $+10 \mathrm{mV}$ or so it was much faster. The magnitude of the slow phase of activation seen with LHRH was variable in different experiments (e.g., it is more prominent in the cell shown in Fig. $8 B$ than that in Fig. $8 A$ ). However, the current never relaxed completely back to control levels, even with the more positive depolarizations.

\section{State dependence of $\mathrm{LHRH}$ inhibition}

The ability of short, large depolarizations or longer, smaller depolarizations to relieve partially inhibition by LHRH suggests that its effect is a change in the gating properties of the channels. Since transmitter appears somehow to affect the gating of the channels, it is interesting to ask how the action of transmitter is affected by the gating state of the channels at the time of transmitter application.

We addressed the state dependence of LHRH inhibition by using rapid application and removal of LHRH during long volt- age steps that activated the channels. Figure 9 shows currents elicited under control conditions and during a fast application of LHRH. The cell was exposed to LHRH for $4 \mathrm{sec}$ during a 9.7-sec-long depolarization. The exposure to LHRH is demarcated by the upward deflections, which are artifacts produced when the cell is briefly exposed to Tyrode's solution while being moved between the outflow of tubes containing $2 \mathrm{Ba}, 160$ TEA solution with and without $1 \mu \mathrm{M}$ LHRH. There is little effect of LHRH applied during the depolarization to $-20 \mathrm{mV}$, as can be seen when the current traces with and without an LHRH application are scaled so that the peak amplitudes are the same (Fig. $9 A$, bottom); the difference in initial current size is due to rundown or incomplete recovery from the inactivation during such long depolarizations. In the same cell, a second application of LHRH (Fig. 9B) for the same 4 sec time period dramatically inhibited current when LHRH was applied at a holding potential of $-90 \mathrm{mV}$ using only short $5 \mathrm{msec}$ depolarizations to $-20 \mathrm{mV}$ to assay Ca channel current. LHRH at concentrations of 0.3-3 $\mu \mathrm{M}$ failed to inhibit $\mathrm{Ba}$ current significantly when applied during $9.7 \mathrm{sec}$ pulses to potentials ranging from -30 to $-10 \mathrm{mV}(n=$ 12), even though all cells had normal responses when LHRH was applied with a normal protocol. Thus, LHRH has little or no effect when applied to channels that are activated and conducting. In one experiment in which LHRH was applied during a long pulse to $-35 \mathrm{mV}$, which barely activated an inward 
A
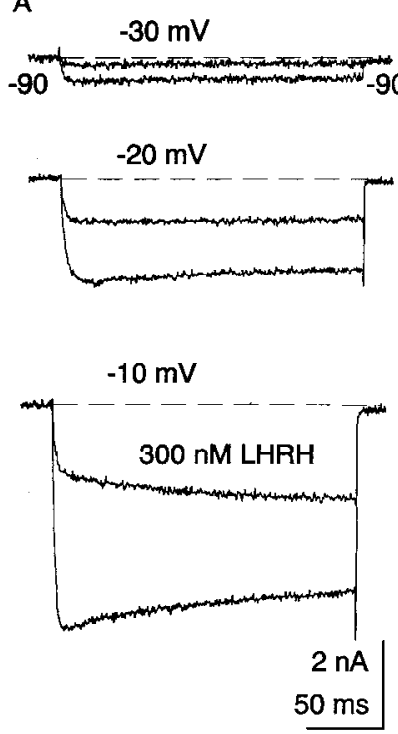

B

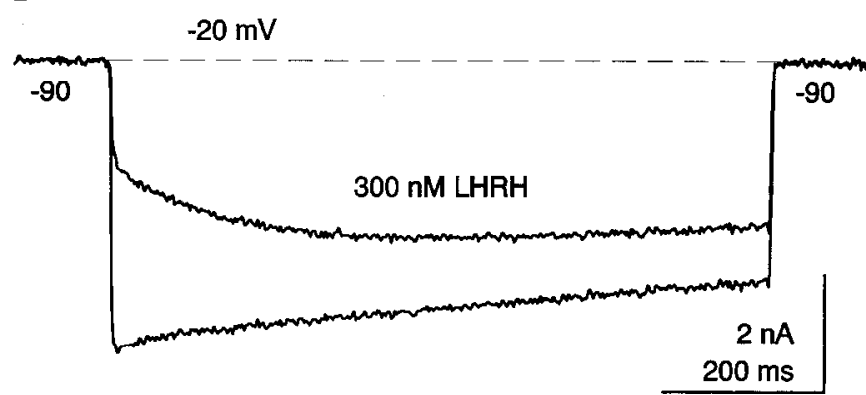

Figure 8. Effect of LHRH on activation kinetics of the $\mathrm{N}$-type current. $A$, In the same cell, voltage steps from -90 to the indicated test potentials were applied for $200 \mathrm{msec}$ in the absence or presence (smaller currents) of $300 \mathrm{~nm} \mathrm{LHRH.} B$, Currents in the absence or presence of $300 \mathrm{nM}$ LHRH were elicited following $800 \mathrm{msec}$ pulses from -90 to $-20 \mathrm{mV}$. All recordings were made with $3 \mu \mathrm{M}$ nimodipine.

current, $1 \mu \mathrm{M}$ LHRH produced a clear inhibition during the application; however, inhibition was seen in only one of three experiments with depolarizations to $-35 \mathrm{mV}$, and the currents were so small it would be hard to quantitate the effect.

We also tested LHRH effects when channels are mostly inactivated. As shown in Figure 10, inhibition by LHRH did not dramatically alter the voltage dependence of inactivation of $\mathrm{N}$-type current. In one protocol, cells were voltage clamped at $-90 \mathrm{mV}$ and the maximum inward current elicited at $-20 \mathrm{mV}$ was measured following a $3 \mathrm{sec}$ prepulse to different membrane potentials between -100 and $-10 \mathrm{mV}$. The reduction in current by LHRH was very similar with prepulses over a range of -100 to $-30 \mathrm{mV}$ (Fig. $10 A$ ). At potentials positive to $-30 \mathrm{mV}$ (where there would have been some activation of channels during the prepulse), LHRH had less effect; however, it is hard to rule out the possibility that there was some desensitization of the effect of I.HRH by the time of these measurements. In five experiments like that in Figure $10 \mathrm{~A}$, the half-inactivation voltage was shifted by only $-2 \pm 3 \mathrm{mV}$ by $0.3-3 \mu \mathrm{M}$ LHRH. In a second protocol, less subject to complications from desensitization, inhibition by $300 \mathrm{~nm}$ LHRH was measured with separate applications from steady holding potentials of either $-90 \mathrm{mV}$ or -50 $\mathrm{mV}$, where a large fraction of the $\mathrm{N}$-type current was inactivated
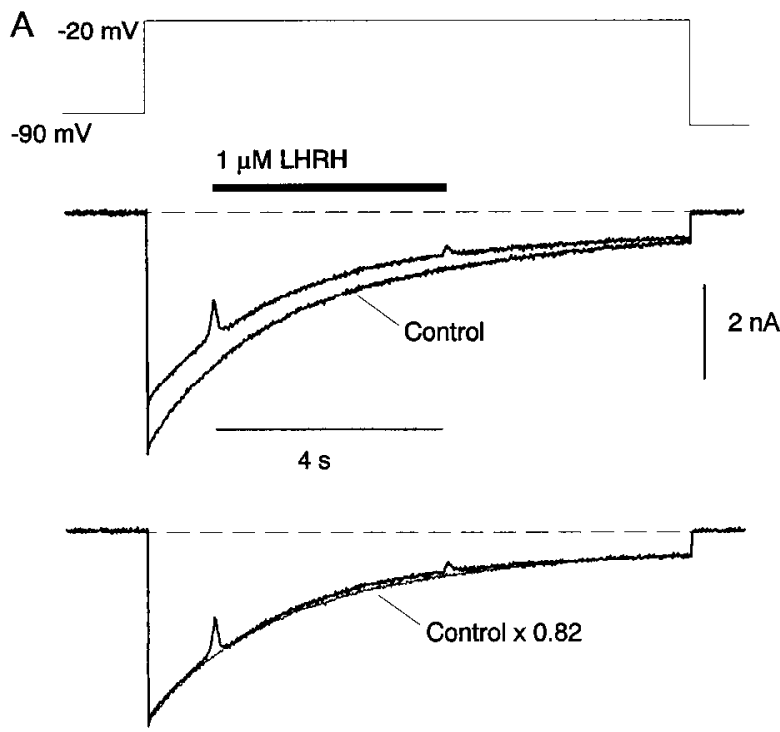

B

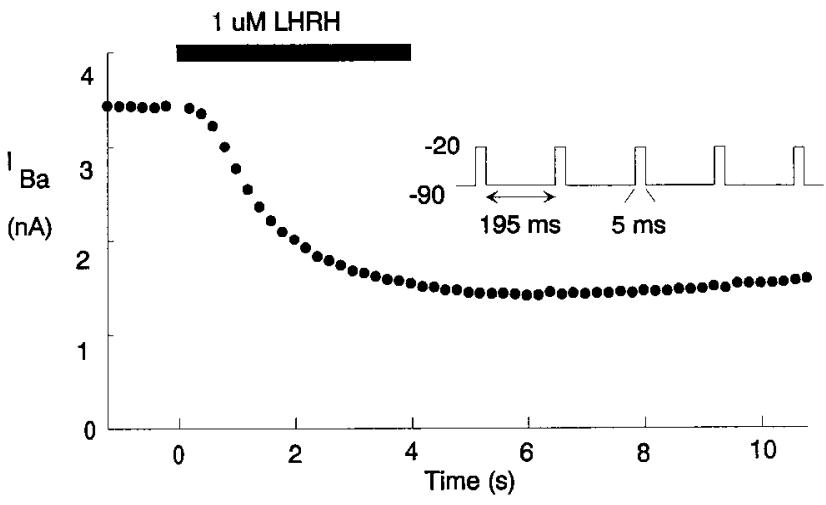

Figure 9. Effect of gating state on inhibition by LHRH. $A$, Two successive currents elicited by 9.7 -sec-long depolarizations from -90 to $-20 \mathrm{mV}$. The two upward deflections present in the smaller current trace are artifacts from the movement of the cell into and out of the solution containing $1 \mu \mathrm{M}$ LHRH. Below, The control current trace is scaled by a factor of 0.82 to match the peak current amplitudes, which differ due to some steady-state inactivation present following these long pulses. $B$, In the same cell, currents were elicited every $200 \mathrm{msec}$ by short depolarizations, and the time of application of $1 \mu \mathrm{M} \mathrm{LHRH}$ is indicated by the bar. All recordings were made with $3 \mu \mathrm{M}$ nimodipine.

(Fig. 10B). Both the time course of development of inhibition and the degree of inhibition were similar at the two holding potentials. $N$-type current was inhibited by $71 \pm 4 \%$ with a $\tau_{\text {on }}$ of $2.6 \pm 0.4 \mathrm{sec}$ at $-90 \mathrm{mV}$, and by $65 \pm 2 \%$ with a $\tau_{\text {on }}$ of 2.7 $\pm 0.5 \mathrm{sec}$ at $-50 \mathrm{mV}(n=6)$. Thus, inhibition by LHRH is nearly the same whether the neurotransmitter is applied with most channels in a resting state $(-90 \mathrm{mV})$ or most channels inactivated $(-50 \mathrm{mV})$.

\section{Facilitation of tail currents}

Elmslie et al. (1990) found that in the presence of LHRH, currents elicited by small depolarizations are enhanced if they closely followed large depolarizations. Such "facilitation" was also seen with channels modulated by internal GTP $\gamma \mathrm{S}$ (Elmslie et al., 1990; Ikeda, 1991; Kasai, 1992) and even under control conditions in rat sympathetic neurons (Ikeda, 1991) and neuroblastoma cells (Kasai, 1992). With internal GTP $\gamma$ S producing channel modulation, Elmslie et al. (1990) found that development of facilitation during a large depolarization reached a lim- 


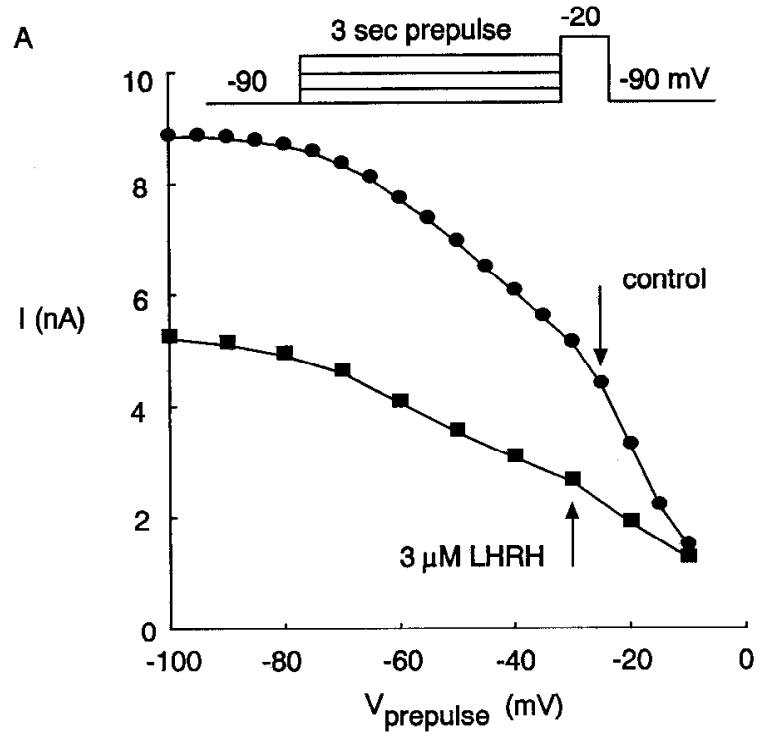

B

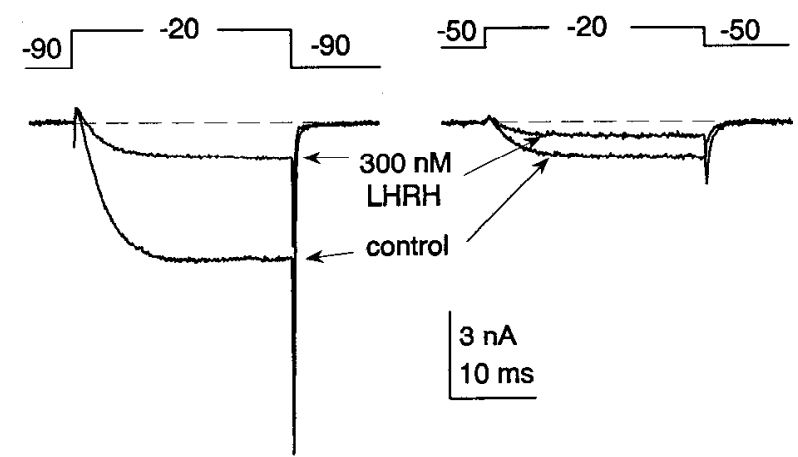

Figure 10. Effect of LHRH on inactivation of N-type current. A, Currents were elicited from $25 \mathrm{msec}$ depolarizations to $-20 \mathrm{mV}$ following a $3 \mathrm{sec}$ prepulse to the indicated membrane potential. The inactivation protocols were run before or during the inhibition by $3 \mu \mathrm{M}$ LHRH in the constant presence of $3 \mu \mathrm{M}$ nimodipine. Arrows indicate the midpoint of inactivation for the control or LHRH-exposed currents, which are $-25 \mathrm{mV}$ and $-30 \mathrm{mV}$, respectively. $B$, Comparison of the degree of inhibition by $300 \mathrm{~nm}$ LHRH at different steady holding potentials. At a holding potential of $-90 \mathrm{mV}$, the maximal inhibition was $73 \%$; at $-50 \mathrm{mV}$, the inhibition was $68 \%$. The holding potential of $-50 \mathrm{mV}$ was established for $85 \mathrm{sec}$ before the second application of LHRH.

iting time constant of about $6 \mathrm{msec}$ for very large depolarizations, and they suggested that this must be considerably slower that the rate of activation, which might be expected to become very rapid at large test depolarizations. Whether facilitation and activation proceed at the same or different rates is a crucial point for distinguishing different models of channel modulation, so we tested this point directly.

The experiment shown in Figure 11 compared the time courses of activation and facilitation in a cell exposed to $300 \mathrm{~nm}$ LHRH. The duration of a depolarization to $+150 \mathrm{mV}$ was varied from 0.5 to $30 \mathrm{msec}$. The activation of channels during the pulse was monitored by plotting the tail current following the pulse (at a tail potential of $-30 \mathrm{mV}$ ) as a function of the pulse duration; facilitation was reflected in an increase in the size of current elicited by a test pulse to $-20 \mathrm{mV}$ given after the step to $+150 \mathrm{mV}$ compared to a test pulse preceding the step to $+150 \mathrm{mV}$. Under control conditions, there was a very
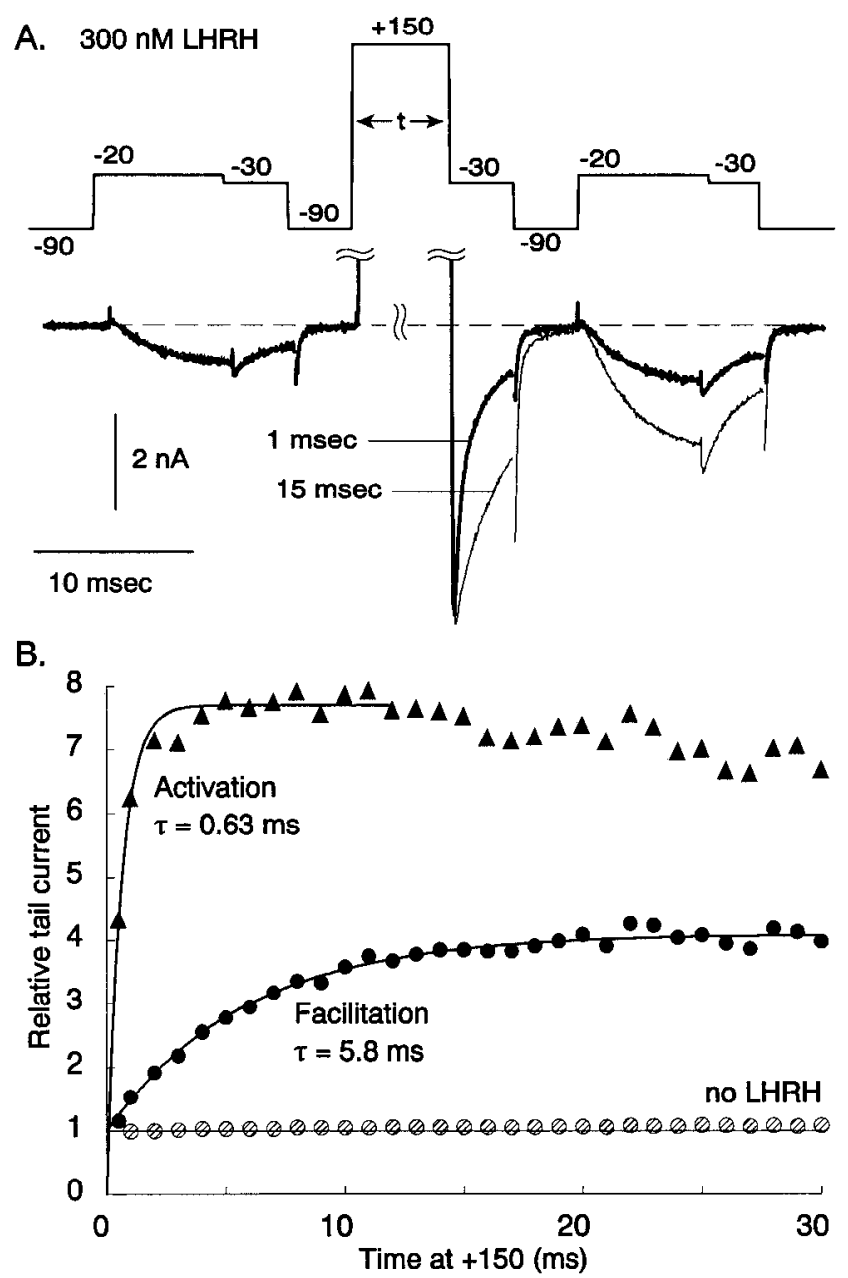

Figure 11. Facilitation contrasted with activation. $A$, The duration of a voltage step to $+150 \mathrm{mV}$ was varied over the range of $0.5-30 \mathrm{msec}$. The time course of activation was determined from the tail current at $-30 \mathrm{mV}$ immediately following steps to +150 of different durations. The time course of facilitation was determined by comparing current elicited by steps to $-20 \mathrm{mV}$ before and after the step to $+150 \mathrm{mV}$. In control, the step to $+150 \mathrm{mV}$ had almost no effect on current elicited by a step to $-20 \mathrm{mV}$. In the presence of $300 \mathrm{nM}$ LHRH, the step to $+150 \mathrm{mV}$ enhanced (facilitated) current elicited by a step to $-20 \mathrm{mV}$. Two current traces are shown, with $1 \mathrm{msec}$ and $15 \mathrm{msec}$ steps to +150 $\mathrm{mV}$; the large outward currents clicited at $+150 \mathrm{mV}$ are omitted to save space, and the currents following the steps to $+150 \mathrm{mV}$ are translated along the time axis to be superimposed. The currents were corrected for leak and capacity currents, using current in response to a step from -90 to $-100 \mathrm{mV}$ appropriately scaled for each voltage epoch. $B$, The time course of activation in $300 \mathrm{~nm}$ LHRH (triangles) is expressed as the magnitude of the tail current following the step to $+150 \mathrm{mV}$, normalized by the tail current following the first step to $-20 \mathrm{mV}$. The decline after $15 \mathrm{msec}$ reflects the beginning of inactivation. Solid line is best fit of a single exponential from 0 to $12 \mathrm{msec}$. The time course of facilitation in $300 \mathrm{~nm}$ LHRH (solid circles) is expressed as the tail current following the second step to $-20 \mathrm{mV}$ normalized by the tail current following the first step to $-20 \mathrm{mV}$. Solid line is best fit of a single exponential over the whole time course. In the absence of LHRH (shaded circles), there was a very small amount of facilitation, about $10 \%$ after a $30 \mathrm{msec}$ step to $+150 \mathrm{mV}$.

small amount of facilitation; the test pulse (or tail current following the test pulse) following a $30 \mathrm{msec}$ depolarization to $+150 \mathrm{mV}$ was enhanced by only about $10 \%$ in the absence of LHRH (Fig. $11 B$, shaded circles). After modulation by $300 \mathrm{~nm}$ LHRH (which reduced the current elicited by a single $8 \mathrm{msec}$ depolarization to $-20 \mathrm{mV}$ from $5.23 \mathrm{nA}$ in control to $0.67 \mathrm{nA}$ ), 
the step to $150 \mathrm{mV}$ produced dramatic facilitation (solid circles), with a fourfold increase in test pulse current following a $25 \mathrm{msec}$ step to $+150 \mathrm{mV}$. Facilitation developed with a time course that could be fit well by an exponential relaxation with a time constant of $5.8 \mathrm{msec}$. In contrast, activation (triangles) developed much more rapidly, with a time constant of 0.63 msec.

Similar results were obtained in a total of four neurons exposed to $300 \mathrm{nM} \mathrm{LHRH}$ in which there was facilitation by at least 1.7-fold (mean, $2.7 \pm 0.5$ ); with the identical voltage protocol as in Figure 11 , the time constant of activation at +150 $\mathrm{mV}$ was $0.62 \pm 0.07 \mathrm{msec}$ while the time constant of facilitation was $4.7 \pm 0.5 \mathrm{msec}$. Although the peak magnitude of the tail current was nearly maximal with a $1 \mathrm{msec}$ depolarization, the kinetics of the tail current changed significantly during the time that facilitation occurred; the decay of the tail current was considerably slower following a $10 \mathrm{msec}$ step to $+150 \mathrm{mV}$ than following a $1 \mathrm{msec}$ depolarization. In contrast, under control conditions there was little or no change in the tail decay with activating pulses of different duration. There was also little or no facilitation under control conditions; a $30 \mathrm{msec}$ predepolarization to $+150 \mathrm{mV}$ produced an average increase of only $3 \pm$ $1 \%$ in current elicited by a step to $-20 \mathrm{mV}$.

\section{Discussion}

\section{Selective inhibition of $N$-type current}

Our results confirm that LHRH is an effective inhibitor of N-type Ca channels in bullfrog sympathetic neurons (Bley and Tsien, 1990; Elmslie et al., 1990). The results fit well with results in many other neurons showing inhibition of $\mathrm{N}$-type channels by a variety of neurotransmitters (e.g., Gross and MacDonald, 1987; Wanke et al., 1987; Bean, 1989; Plummer et al., 1989). In our experiments, the effects of LHRH were selective for N-type over L-type channels. Such selective modulation of N-type but not L-type channels has been reported previously for experiments with norepinephrine on frog and rat sympathetic neurons (Lipscombe et al., 1989; Plummer et al., 1989, 1991), adenosine, norepinephrine, and GABA on chick neurons (Kasai and Aosaki, 1989; Cox and Dunlap, 1992), and $\delta$-opioid receptor agonists on neuroblastoma cells (Kasai, 1992). [In some cases, though, some transmitters can also inhibit L-type channels, perhaps by different pathways (e.g., Maguire et al., 1989; Fisher and Johnston, 1990; Bernheim et al., $1991 \mathrm{a}, \mathrm{b})$.] Our results contrast with those of Bley and Tsien (1990), who reported inhibition by LHRH of both N-type and L-type channels in frog sympathetic ganglion neurons; reasons for the difference are not obvious since both studies used similar protocols testing for LHRH effects on Bay K 8644-modified tail currents.

\section{Voltage dependence of modulation}

As in previous studies with norepinephrine (Bean, 1989; Beech et al., 1991, 1992), dynorphin A (Bean, 1989), 5-HT (Penington et al., 1991), and LHRH (Elmslie et al., 1990), tail currents were inhibited less following pulses to very large depolarizations than for small and moderate depolarizations. In all our experiments, however, cven tail currents following the largest depolarizations were somewhat depressed, so that the modulation cannot be described as only a change in voltage dependence of the channels. Some depression of tail currents following large depolarizations is seen in most other examples of transmitter modulation. For example, norepinephrine studied on $\mathrm{Ca}$ channels in frog sensory neurons showed an average inhibition of $15 \%$ fol- lowing pulses to +130 to $+150 \mathrm{mV}$, compared to $54 \%$ following small and moderate depolarizations (Bean, 1989). An exception to the voltage-dependent effects seen in most studies was reported for $\mathrm{GABA}_{\mathrm{B}}$ receptor stimulation in rat sensory neurons, where Dolphin and Scott (1990) found equal inhibition of $\mathrm{Ca}$ currents elicited by moderate and large depolarizations. In our experiments, we do not know whether the small inhibition by LHRH at large depolarizations is somehow separable from the larger effects at smaller depolarizations, but there was no obvious difference in the time course of development or reversal. In rat sympathetic neurons, Beech et al. (1992) suggest that there may be different fast pathways giving voltage-dependent and voltage-independent modulation.

The relief of inhibition following short, large depolarizations seems closely related to the relief of inhibition seen as a slow phase of activation during smaller depolarizations, which has also been reported previously in many systems beginning with GABA inhibition of Ca current in chick dorsal root ganglion (DRG) neurons (Diesz and Lux, 1985; Marchetti et al., 1986) and somatostatin inhibition in a pituitary cell line (Lewis et al., 1986). In our experiments, such a slow phase of activation was always evident in the presence of LHRH, but current in the presence of transmitter never relaxed all the way back to control values. Similar results have been seen in most other systems, although in a few cases currents in transmitter do relax all the way back to control levels with long enough pulses (e.g., Kasai and Aosaki, 1989; Penington et al., 1991; Kasai, 1992).

\section{Kinetics}

At concentrations above $0.5 \mu \mathrm{M}$, the kinetics of LHRH onset become concentration independent, with a limiting time constant of 2 sec. The results with high agonist concentrations fit well with those of Jones (1991), who found similar kinetics using teleost LHRH and norepinephrine. Recovery from inhibition was slower in our experiments $(\tau \sim 19 \mathrm{sec})$ than in his $(\tau \sim 2$ sec). This would be consistent with recovery being limited by unbinding of LHRH in our experiments, since we used chicken LHRH type II, which acts with 10-fold higher potency $\left(\mathrm{EC}_{50} \sim\right.$ $20 \mathrm{~nm}$ ) than teleost LHRH (Jones, 1991). But in other experiments, we observed recovery with a $\tau$ of $\sim 18 \mathrm{scc}$ from inhibition by norepinephrine, five to six times slower than reported by Jones with norepinephrine, so there may also be differences arising from solutions or experimental conditions.

As discussed by Jones (1991), development with a limiting time constant of a second or two is faster than $\beta$-adrenergic modulation of cardiac Ca channels, which is mediated by a cAMP/protein kinase cascade and takes many seconds to reach completion (e.g., Bean et al., 1984), but slower than muscarinic activation of cardiac $\mathrm{K}$ current, most likely mediated by direct $\mathrm{G}$-protein binding to $\mathrm{K}$ channels, which takes less than a second to be complete (Breitwieser and Szabo, 1988). The kinetics of LHRH inhibition of Ca channels seem consistent with either a fast-acting second messenger system or with direct binding of G-proteins to channels (e.g., Brown and Birnbaumer, 1988; Yatani and Brown, 1989).

The data in Figure 4 are consistent with the picture that LHRH binding and unbinding from its receptor might control both the rate of recovery and the rate of onset at low $(<0.3 \mu \mathrm{M})$ concentrations, but with some other process becoming rate limiting when LHRH binding becomes faster than a second or two. With this picture, LHRH would unbind with a rate constant of $\sim 0.05$ $\sec ^{-1}$ (giving $\tau_{\text {off }}$ of $\sim 20 \mathrm{sec}$ ) and bind with a rate constant of 
A

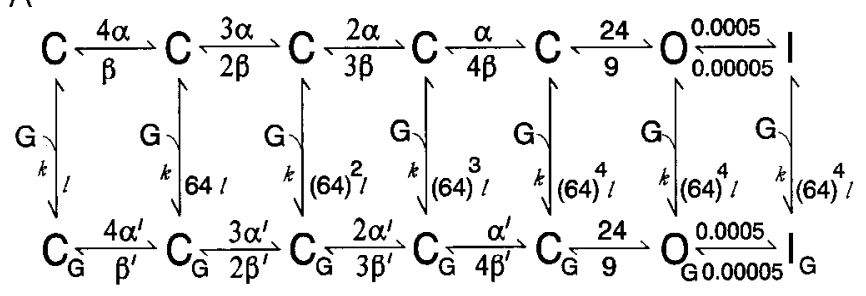

$$
\begin{array}{ll}
\alpha=0.9 \exp (\mathrm{V} / 22) \mathrm{msec}^{-1} & \alpha^{\prime}=(1 / 8)^{\star} \alpha \\
\beta=0.03 \exp (-\mathrm{V} / 14) \mathrm{msec}^{-1} & \beta^{\prime}=8 * \beta
\end{array}
$$
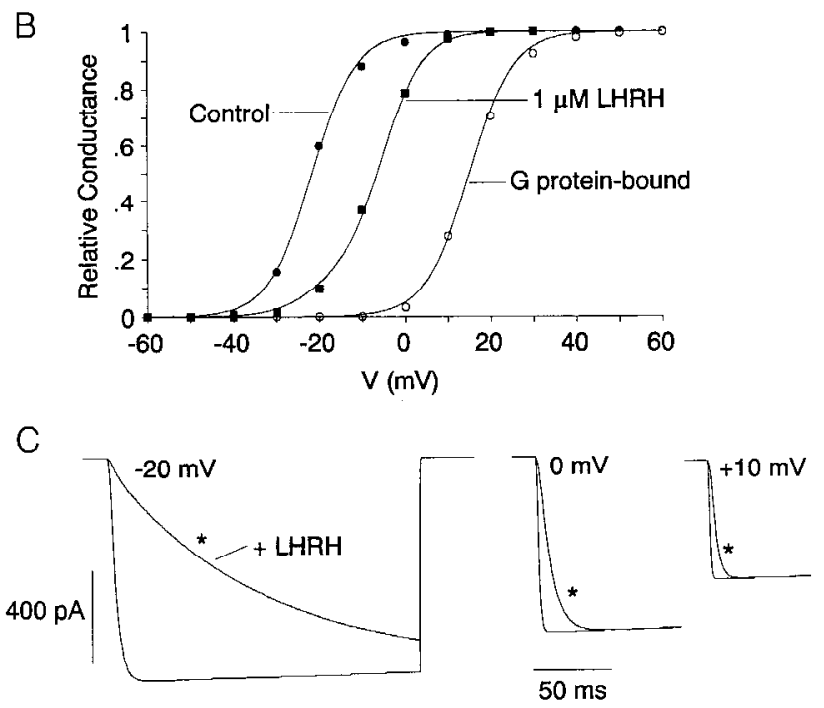

Figure 12. A, A simple model for modification of Ca channel gating by binding of a G-protein. Channel gating is governed by four subunits; when all four subunits have moved to an activated position, channels can undergo a final voltage-independent step to the open state. Activated G-proteins are assumed to bind reversibly to $\mathrm{Ca}$ channels. With G-protein bound, activation of each subunit is slowed by a factor of 8 and deactivation is speeded by a factor of 8 , such that larger depolarizations are required to open channels. Activation of subunits in G-protein-bound channels destabilizes the binding of the G-protein, expressed as an acceleration of unbinding. As channels are more activated by depolarization, G-protein unbinds increasingly quickly. For the simulations shown in $B$ and $C$, the on rate constant for G-protein binding was $0.003 *[\mathrm{LHRH}] /(68+[\mathrm{LHRH}]) \mathrm{msec}^{-1}$ (with nanomolar [LHRH]) and the off rate constant with no subunits activated was $0.00025 \mathrm{msec}^{-1}$. The form of the on rate constant is consistent with a limiting population of G-proteins, the rate of formation of activated G-proteins being proportional to the fractional occupancy of LHRH receptors and with a constant rate of deactivation of G-proteins by GTP hydrolysis. The on rate constant was chosen to predict a time constant of about $300 \mathrm{msec}$ for G-protein binding to resting channels with saturating LHRH, an upper limit of experimentally reasonable values. The off rate constant was chosen to yield inhibition to $15 \%$ with a depolarization to -20 $\mathrm{mV}$, similar to the larger effects of LHRH seen experimentally. $B$, Activation curves for control channels (solid circles), G-protein-bound channels (open circles), and channels in the presence of $1 \mu \mathrm{M} \mathrm{LHRH}$ (squares). Activation curves were constructed from simulated currents for $15 \mathrm{msec}$ voltage steps from $-90 \mathrm{mV}$ to different voltages, with tail currents measured on repolarization to $-40 \mathrm{mV}$. Tail current was normalized to that following a step to $+100 \mathrm{mV}$. For the activation curve of G-protein-bound channels, channels were constrained to remain $G$-protein bound (i.e., there was no unbinding of $G$-protein during the depolarizations). With $1 \mu \mathrm{M}$ LHRH, $90 \%$ of the channels were initially G-protein bound at $-90 \mathrm{mV}$; for depolarizations beyond $0 \mathrm{mV}$, there was substantial unbinding of $\mathrm{G}$-protein during the $15 \mathrm{msec}$ depolarization (essentially complete unbinding for steps to $+10 \mathrm{mV}$ and beyond). Control data are fit with single Boltzmann curve: $1 /\left(1+\exp \left(-V-V_{h}\right) /\right.$ $k$ ), with $V_{\mathrm{h}}=-22 \mathrm{mV}, k=5.1 \mathrm{mV}$. Data points for G-protein-bound $\sim 3 \times 10^{6} \mathbf{M}^{-1} \mathrm{sec}^{-1}$ (giving $\tau_{\text {on }}$ of $\sim 13 \mathrm{sec}$ at $10 \mathrm{nM} \mathrm{LHRH}$ ), with a predicted $K_{d}$ of $\sim 20 \mathrm{nM}$, as observed. However, there is no direct evidence that the rate of recovery is limited by LHRH unbinding from its receptor rather than some other process.

\section{Models for modulation}

Marchetti et al. (1986) suggestcd that slow activation induccd by transmitters might reflect voltage-dependent removal of transmitter inhibition. Many subsequent experiments have supported this idea. The removal of inhibition seems unlikely to reflect actual voltage-dependent unbinding of transmitter molecules, since the phenomenon can be seen in the absence of any transmitter if GTP $\gamma \mathrm{S}$ is used to activate G-proteins.

Another possibility is that the voltage-dependent effects of transmitters are related to the voltage-dependent gating of the channels themselves. The effects of transmitters in changing the voltage dependence of calcium channels can be rationalized by supposing that transmitters induce or stabilize a "reluctant" mode of gating of the channel, for which activation is shifted in the depolarizing direction (Bean, 1989). The hypothesis explains the slow phase of channel activation as a slow conversion of reluctant to willing channels, driven by mass action at voltages where willing channels mostly open but reluctant channels do not. Elmslie et al. (1990) added the idea that activated channels, as well as resting channels, can interconvert between reluctant and willing modes of gating, and they showed that this idea can account for their observation that large depolarizations longer than $10 \mathrm{msec}$ not only open reluctant channels but also produce relatively long-lasting facilitation by converting reluctant to willing channels.

A specific possibility is that the reluctant mode represents gating of channels modified by direct binding of activated $\mathrm{G}$-proteins to the channel. If G-protein binding stabilizes closed states of the channel, the voltage dependence of gating would be shifted in the depolarizing direction. Conversions between willing and reluctant modes of gating-facilitation and recovery from facilitation - would then represent binding and unbinding of G-proteins.

We explored the predictions of this hypothesis by making kinetic models. Binding and unbinding of G-proteins must follow the law of mass action, and the principle of microscopic reversibility requires that if binding of G-protein induces a shift in voltage-dependent gating, then gating of the channels must produce a change in the affinity of G-protein binding. By making specific kinetic models, we wanted to test whether the voltageand time-dependent phenomena seen with transmitter modulation can be predicted using physically realistic rate constants within the constraints imposed by the laws of mass action and microscopic reversibility.

We used a model for channel gating based on current models

channels are fit with a single Boltzmann curve with $V_{h}=+15 \mathrm{mV}, k$ $=5.4 \mathrm{mV}$. Data points for $1 \mu \mathrm{M} \mathrm{LHRH}$ are fit by the sum of two Boltzmann curves: $0.15 /(1+\exp ((-V-(-22)) / 5.1))+0.85 /(1+$ $\exp ((-V-(-5)) / 4.6))$; the fit was made by setting the first component (based on inhibition to $15 \%$ at $-20 \mathrm{mV}$ ) and allowing the midpoint of voltage and slope of the second component to vary. $C$, Simulated currents with (asterisks) and without $1 \mu \mathrm{M}$ LHRH at $-20,0$, and $+10 \mathrm{mV}$. Simulations used a holding potential of $-90 \mathrm{mV}$ and $200 \mathrm{msec}$ depolarizations (of which only $80-100 \mathrm{msec}$ are shown for the two larger steps). 
for gating of voltage-dependent potassium and sodium channels (Zagotta and Aldrich, 1990; Koren et al., 1990; Vandenberg and Bezanilla, 1991). We modeled two specific hypotheses for binding of G-proteins to the channels. In the simplest, channels are assumed to be modulated by binding of a single G-protein molecule (Fig. 12). While relatively easy to formulate and solve, this model proved incapable of accounting for some aspects of experimental behavior. $\Lambda$ more realistic model in which four G-proteins can bind to a channel (Fig. 13) gave more accurate predictions of experimental results, and this model is presented in greater detail (Figs. 14-17).

The simpler model in Figure 12 is an expanded version of the model of Elmslie et al. (1990) that uses a more detailed scheme for channel gating; the model explicitly proposes that channels are made reluctant by binding of $\mathrm{G}$-protein to the channel and that conversion between reluctant and willing modes reflects binding and unbinding of $\mathrm{G}$-proteins. The gating of unmodified channels is modeled using five closed states, an open state, and an inactivated state (Fig. 12, top row). Gating between the closed states occurs with voltage-dependent rate constants that would correspond to four identical, independent subunits, each gating between a nonpermissive (nonactivated) and a permissive (activated) state (Zagotta and Aldrich, 1989; Koren et al., 1990). This allows modeling of activation and deactivation using only two voltage-dependent rate constants, the forward rate constant $\alpha(V)$ and the back rate constant $\beta(V)$. As in models for $\mathrm{Na}$ and $\mathrm{K}$ channels, it is assumed that activation of all four subunits is not sufficient to produce channel opening; there is a final opening step that is not voltage dependent. Inactivation occurs only from the open state, with a voltage-independent rate constant of $0.0005 \mathrm{msec}^{-1}$. The parameters of the model were adjusted by trial and error to give a reasonable approximation of channel voltage dependence and gating kinetics. The values of the rate constants for the final opening step (opening rate constant of $24 \mathrm{msec}^{-1}$ and closing rate constant of $9 \mathrm{msec}^{-1}$ ) were chosen to predict a maximal open probability of about 0.75 (consistent with unpublished noise analysis data, L. M. Boland and B. P. Bean) and to give a simulated tail current at $-90 \mathrm{mV}$ deactivating with a time constant of $0.17 \mathrm{msec}$, as seen experimentally.

In the model in Figure 12, only one G-protein binds to a channel. G-proteins bind to the channel with a first-order rate constant and unbind with a zero-order rate constant. Simulations were done assuming that with $1 \mu \mathrm{M}$ LHRH the rate constant for G-protein binding is $0.0026 \mathrm{msec}^{-1}$ and the rate constant for unbinding is $0.00025 \mathrm{msec}^{-1}$. The ratio of the on and off ratc constants was chosen to lcave about $10 \%$ of the channels unbound, so that the simulations predicted inhibition of current to $\sim 15 \%$ (near the maximal effect seen experimentally) when assayed with a $15 \mathrm{msec}$ step to $-20 \mathrm{mV}$ (during which a few initially bound channels open by losing their G-protein). With these on and off rate constants, G-protein binding is predicted to occur with a time constant of $\sim 350 \mathrm{msec}$ for resting channels. Making the time course any slower seemed unreasonable, since experimental tests suggest rebinding G-protein with time constants of 100-200 msec (Elmslie et al., 1990; Lopez and Brown, 1991; Penington et al., 1991).

With G-protein bound, closed states of the channel are stabilized and activation is shifted to more positive voltages (Fig. $12 B$ ). This is implemented by assuming that for G-protein-bound channels the activation rate constant $\alpha(V)$ is decreased by a factor of 8 and the deactivation rate constant $\beta(V)$ is increased by a factor of 8 . The $\mathrm{G}$-protein-bound channels (open

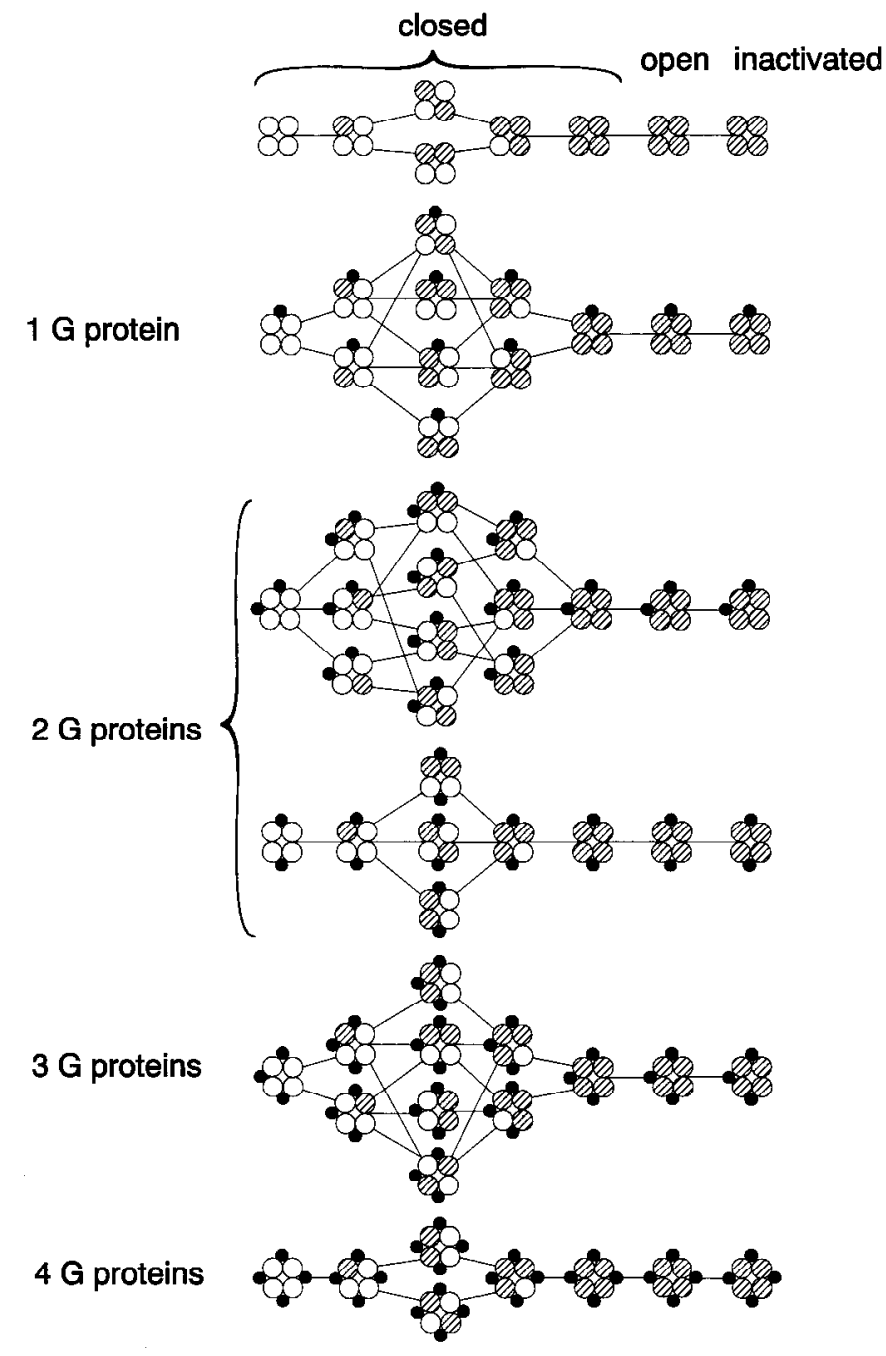

Figure 13. A model for channel modulation by binding of four G-proteins per channel. The kinetic scheme and rate constants for unbound channels (top row) are the same as in Figure 12. Movement of a pseudosubunit to the activated (permissive) state is indicated by shading. G-proteins (small solid circles) are hypothesized to bind to the channel, with a single G-protein making contact with two of the four pseudosubunits (large circles) making up the channel. The forward rate constant for pseudo-subunit gating $\alpha(V)$ is multiplied by $1 / 4$ if a subunit contacts one G-protein and by $1 / 16$ if it contacts two G-proteins; similarly, the back rate constant $\beta(V)$ is multiplied by 4 if a subunit contacts one $G$-protein and by 16 if it contacts two $G$-proteins. The vertical binding and unbinding steps are not shown in the figure. The on rate for G-protein binding is $0.001 *[\mathrm{LHRH}] /(68+[\mathrm{LHRH}]) \mathrm{msec}^{-1}$ per open binding site and is the same for all activation states of the channel. The off rate is $0.0012 \mathrm{msec}^{-1}$ for a channel with no subunits activated, 16 times higher if one subunit contacting the G-protein has activated, and 256 $\left(=16^{2}\right)$ times higher if both subunits contacting the G-protein have activated.

circles) then have an activation curve shifted about $35 \mathrm{mV}$ positive compared to control, similar to the shift seen experimentally. According to the principle of microscopic reversibility, if G-protein binding stabilizes nonactivated states of the channel, then activation of a channel must destabilize the binding of G-protein. This is implemented by increasing the rate constant for unbinding of G-protein by a factor corresponding to the change in activation and deactivation rates and the number of subunits that have moved. For example, with $\alpha(V)$ decreased by a factor of 8 and $\beta(V)$ increased by a factor of 8 , unbinding of G-protein from state $C 4$ (where three subunits 

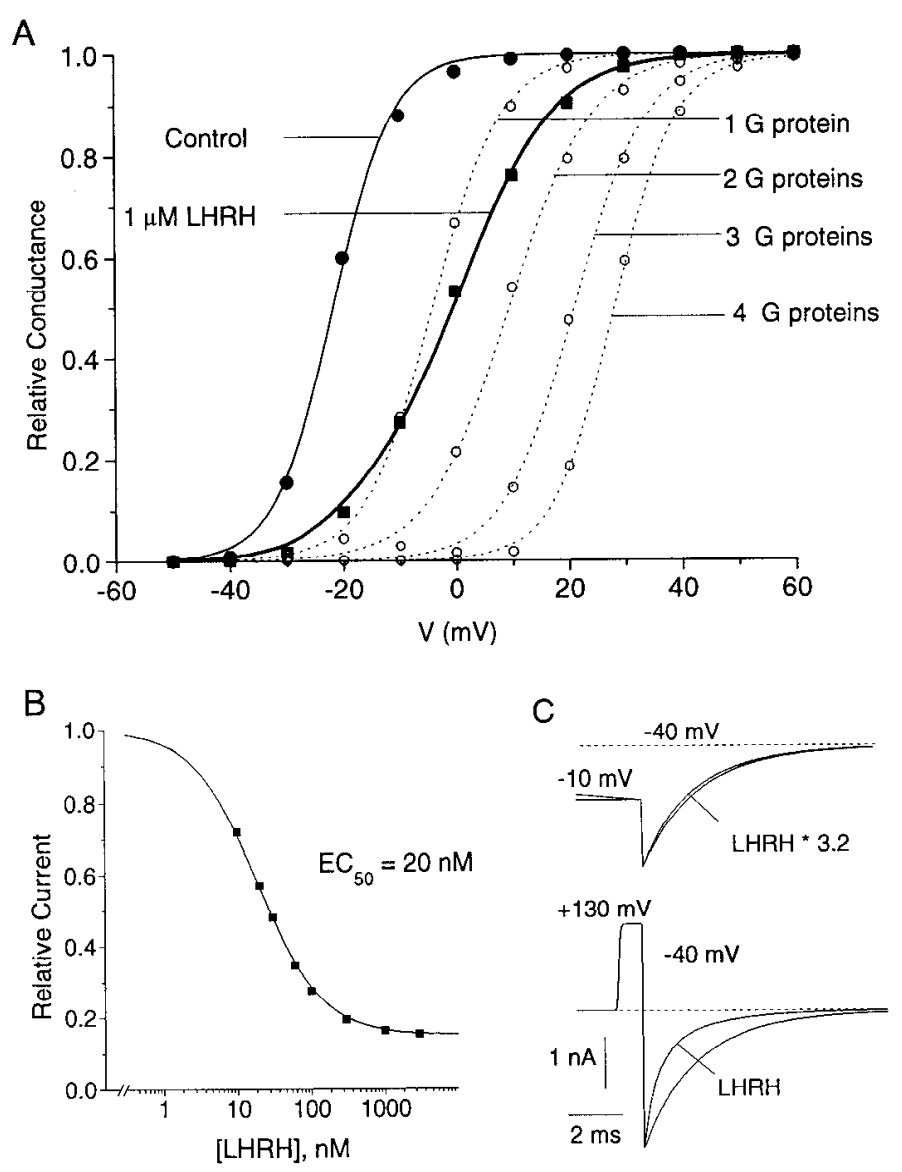

Figure 14. Predictions from four G-protein model. $A$, Activation curves determined by $15 \mathrm{msec}$ depolarizations from $-90 \mathrm{mV}$ to different test potentials; tail current for a step back to $-40 \mathrm{mV}$ was measured immediately after the test step, and the tail currents were normalized to that elicited by a step to $+100 \mathrm{mV}$. The activation curves for channels with one, two, three, and four G-proteins bound were determined by artificially placing all channels into a particular G-protein-bound resting state and not allowing binding or unbinding during the voltage steps. The control and G-protein-bound "data" points are fit with a single Boltzmann curve of the form $\left(1 /\left(1+\exp \left(\left(V-V_{h}\right) / k\right)\right)\right)$, with $V_{h}=-22$ $\mathrm{mV}, k=5.2 \mathrm{mV}$ for control; $V_{h}=-4 \mathrm{mV}, k=6.1 \mathrm{mV}$ for one G-protein; $V_{h}=+9 \mathrm{mV}, k=7.2$ for two G-proteins; $V_{h}=+21 \mathrm{mV}, k=6.4 \mathrm{mV}$ for three G-proteins; and $V_{h}=+28 \mathrm{mV}, k=5.4 \mathrm{mV}$ for four G-proteins. With $1 \mu \mathrm{M}$ LHRH, at $-90 \mathrm{mV}$ there are $10 \%, 31 \%, 36 \%, 19 \%$, and $4 \%$ of the channels with zero, one, two, three, and four G-proteins bound. The data points for $1 \mu \mathrm{M} \mathrm{LHRH}$ are fit with the sum of two Boltzmann curves, one set at $10 \%$ (the fraction of unmodified channels) with the parameters of the control channels $\left(V_{h}=-22 \mathrm{mV}, k=5.2 \mathrm{mV}\right)$, and the other $(90 \%)$ with $V_{h}=+1 \mathrm{mV}$ and $k=8.1$, determined by a best least-squares fit. For small depolarizations, the activation curve for 1 $\mu \mathrm{M}$ LHRH approximates a weighted average of the activation curves for different numbers of $G$-proteins, but at large depolarizations there is considerable unbinding of G-proteins during the $15 \mathrm{msec}$ depolarization. $B$, Simulated dose-response relationship determined using 15 msec depolarizations from $-90 \mathrm{mV}$ to $-20 \mathrm{mV}$. Solid line is drawn according to $0.15+0.85 /(1+[\mathrm{LHRH}] / 20 \mathrm{nM})$. $C$, Simulated tail currents in control and with $1 \mu \mathrm{M} \mathrm{LHRH}$ following a $15 \mathrm{msec}$ depolarization to $-10 \mathrm{mV}$ (top) or a $1 \mathrm{msec}$ depolarization to $+130 \mathrm{mV}$, as for the experimental protocol in Figure 7.

have moved) is increased by a factor of $(64)^{3}$ compared to state C1. The model predicts the broad features of transmitter effects: shift of activation to more positive voltages, a slow phase of activation (corresponding to slow loss of $\mathrm{G}$-protein from partially activated states) that gets faster with increasing depolarization (Fig. 12C), and facilitation that results from unbinding of G-protein. The quantitative predictions of the model, however, had serious discrepancies with the experimental data. The model predicts that gating of G-protein-bound channels is shifted to more positive voltages, but the steepness of the phase of activation induced by transmitter is similar to the control (Fig. $12 B$ ). In contrast, in all experiments, the shifted component of activation induced by transmitter (Fig. 6C; Bean, 1989; Beech et al., 1992) or thought to correspond to G-protein modification (Elmslie et al., 1990; Ikeda, 1991) has a less steep voltage dependence than the control activation curve. Also, when the rate of $\mathrm{G}$-protein binding was adjusted to give an onset of binding (at resting potentials) with a time constant of $350 \mathrm{msec}$, the rate of unbinding at depolarized voltages was far too fast. As shown in Figure $12 C$, the slow activation phase at $-20 \mathrm{mV}$ (which reflects mainly unbinding of G-protein and subsequent activation of the normal channel) has reasonable kinetics $(\tau \sim 130$ msec) but the slow activation phase at $0 \mathrm{mV}$ and above is much faster than seen experimentally. It proved impossible with this model to produce shifts in gating as large as those seen experimentally. The activation curve for G-protein-bound channels can be shifted by arbitrarily large amounts, but when G-proteins have large effects on $\alpha$ and $\beta$ in the model, the rate of unbinding of G-proteins from partially activated channels is so fast that channels do not remain G-protein bound during a 10-15 msec depolarization except for the smallest depolarizations. For example, with the parameters in Figure 12, G-proteins unbind nearly completely within $15 \mathrm{msec}$ for depolarizations beyond $+10 \mathrm{mV}$, such that there is no inhibition remaining at the end of a test pulse.

Since channel gating is hypothesized to be given by four subunits (or, strictly, pseudo-subunits in a single polypeptide), it may be more realistic to allow binding of multiple G-proteins to a single channel. The consequences of allowing multiple $\mathrm{G}$-protein binding were explored using two models. In one, G-protein could bind to each of four subunits, with binding affecting the gating of only that subunit. This model proved incapable of simultaneously accounting for an appropriate shift in gating and reasonable rates of $\mathrm{G}$-protein binding and unbinding at different voltages. In the other model, shown in Figure 13, each G-protein is considered to affect the gating of each of two subunits, as might occur if the G-protein bound between the subunits. This model proved capable of accounting for many of the experimental observations with reasonable quantitative predictions. Predictions from this model are explored in Figures 14-17.

In the model of Figure 13, binding of a G-protein is assumed to stabilize the closed conformation of each of the two subunits it contacts. As in the simpler model, this stabilization is expressed by slowing of the activation rate $\alpha(V)$ and speeding of the deactivation rate $\beta(V)$; for simplicity, the effects on activation and deactivation rate constants are assumed to be symmetric. If a subunit contacts one $\mathrm{G}$-protein, its activation rate is slowed by a factor of 4 and its deactivation rate is speeded by a factor of 4 . If a subunit contacts two G-proteins, its activation is slowed by factor of $4^{2}$ and its deactivation is speeded by factor of $4^{2}$. As required to satisfy microscopic reversibility, the binding of a G-protein is destabilized if one of the subunits it contacts has activated, and is further destabilized if both subunits it contacts have activated. The rate constant for G-protein for unbinding is speeded by a factor of 16 if one subunit has activated and by a factor of $16^{2}$ if two subunits have activated. The resulting kinetic model has many states, because 
many possible combinations of the subunits with one or two G-proteins must be distinguished, but the individual rate constants are determined by these simple rules.

The concentration of activated G-proteins is assumed to be related to LHRH concentration by $[\mathrm{G}]=\mathcal{c}_{1} *\left([\mathrm{LHRH}] /\left(c_{2}+\right.\right.$ [LHRH])), where $c_{1}$ and $c_{2}$ are constants; this is the form expected if there is a saturating concentration of activated G-proteins, with the rate of formation of activated G-proteins proportional to the fractional occupancy of LHRH receptors and with a constant rate of deactivation of G-proteins by GTP hydrolysis. The on rate for G-protein binding is $0.001 *[\mathrm{LHRH}] /$ $(68+[\mathrm{LHRH}]) \mathrm{msec}^{-1}$ per open binding site (the form that follows for first-order binding of activated G-proteins) and is the same for all activation states of the channel; the unbinding rate is $0.0012 \mathrm{msec}^{-1}$ for a G-protein contacting two nonactivated subunits and is multiplied by a factor of 16 if one subunit is activated and by 256 if both subunits are activated. The relative on and off rates were chosen so that the experimental dose-response curve was mimicked (Fig. 14B); the absolute rates were chosen by adjusting the unbinding rate to give a reasonable simulation of the experimental phenomena reflecting unbinding: slow activation of modified channels (Fig. 15) and facilitation (Fig. 16).

As shown in Figure 14A, the model predicts that transmitter induces a component of activation that is shifted in the positive direction and also has a more shallow slope. Channels with one, two, three, or four G-proteins bound have activation curves shifted by increasing amounts from control; the LHRH-altered activation curve approximates a weighted average of these (together with a fraction of unbound channels), with a less steep slope than any individual species. With $1 \mu \mathrm{M} \mathrm{LHRH}$, the fractions of channels at rest with zero, one, two, three, and four G-proteins bound were $0.10,0.31,0.36,0.19$, and 0.04 . The activation curve simulated using $15 \mathrm{msec}$ depolarizations approximates a weighted average of the individual activation curves, but the approximation is not precise because for larger depolarizations some channels lose one or more G-proteins during the depolarization.

Figure $14 C$ shows tail currents predicted by the model. As with experimental tail currents, LHRH induces only a slight speeding of tail currents following moderate depolarizing steps, but there are much more dramatic changes for tail currents following a large, short depolarization. For small and moderate depolarizations, most channels that open have either no or only one G-protein bound, so that the rate of deactivation is minimally different from control. Short large depolarizations can open channels with multiple G-proteins bound, and for these the rate of deactivation is much faster. For longer steps to strongly depolarized potentials, the activated channels lose their G-proteins and are in the unbound state by the time of repolarization, so that tail kinetics revert to normal (e.g., Fig. 17). Thus, the model accounts in a natural manner for the experimental observation that large effects on tail currents are seen only for short large depolarizations.

\section{Discrimination between models}

The central idea in the model shown in Figure 13 is that the kinetic events of slow activation and facilitation reflect unbinding of G-protein from the channel, with recovery from facilitation reflecting rebinding of G-protein. The model is an extension of the model of Elmslie et. al. (1990), incorporating the speculation that modified gating may be a direct consequence
A
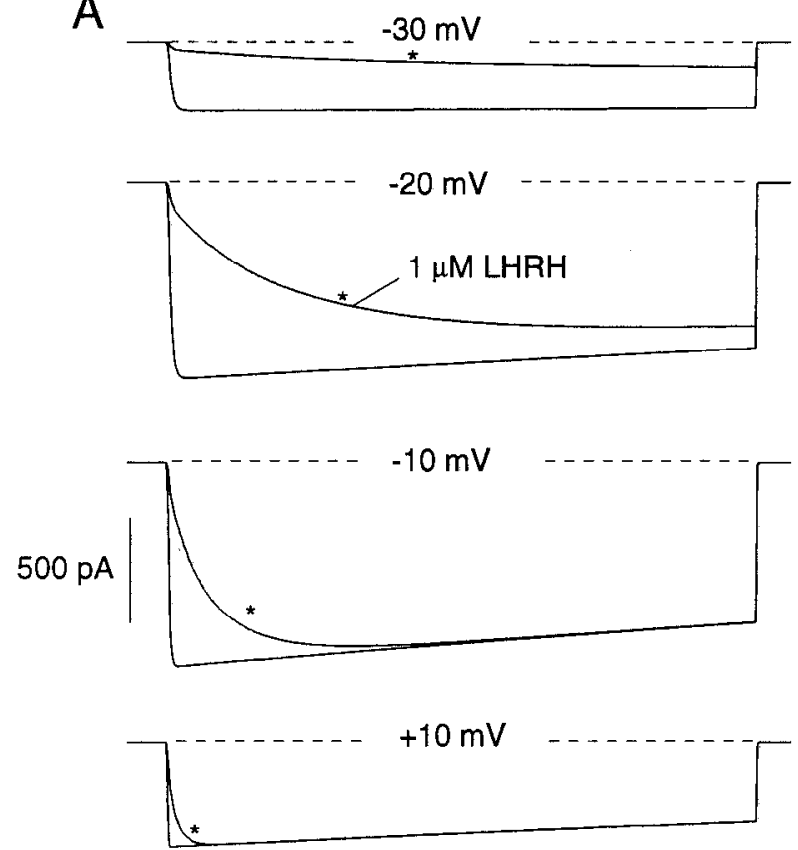

$200 \mathrm{~ms}$

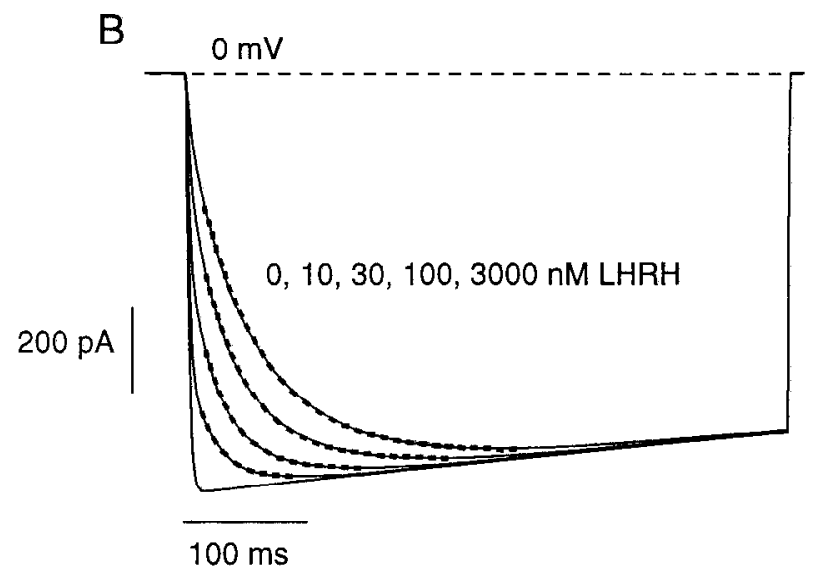

Figure 15 Simulation of slow activation with the four G-protein model. $A$, Slow activation during $800 \mathrm{msec}$ steps to $-30,-20,-10$, and $+10 \mathrm{mV}$. Asterisks, with $1 \mu \mathrm{M}$ LHRH. $B$, Simulation of currents elicited by a $500 \mathrm{msec}$ step to $0 \mathrm{mV}$ with $10,30,100$, and $3000 \mathrm{nM} \mathrm{LHRH.}$ The slow phase of activation is fit with a single exponential (dashed lines), with time constants of $19 \mathrm{msec}(10 \mathrm{nM}), 26 \mathrm{msec}(30 \mathrm{nM}), 38$ msec $(100 \mathrm{~nm})$, and $52 \mathrm{msec}(3000 \mathrm{~nm})$. Fits were also made after "correction" for inactivation by dividing current with LHRH by control current; these gave similar values of $25 \mathrm{msec}(10 \mathrm{nM}), 34 \mathrm{msec}(30 \mathrm{nM})$, $49 \mathrm{msec}(100 \mathrm{~nm})$, and $68 \mathrm{msec}$ (3000 nM) (not shown).

of G-protein binding. A different model for transmitter modulation of Ca channels (Kasai and Aosaki, 1989; Kasai, 1992) proposes that G-protein binding induces a modified gating state of the channel, with slow activation, facilitation, and recovery from facilitation reflecting slow gating transitions in a channel continually modified by G-protein binding. Kasai and Aosaki (1989) found that the time constant of slow activation induced by 2 -chloroadenosine in chick DRG neurons was not dependent on agonist concentration. They suggested that this observation provided evidence against models involving binding and un- 

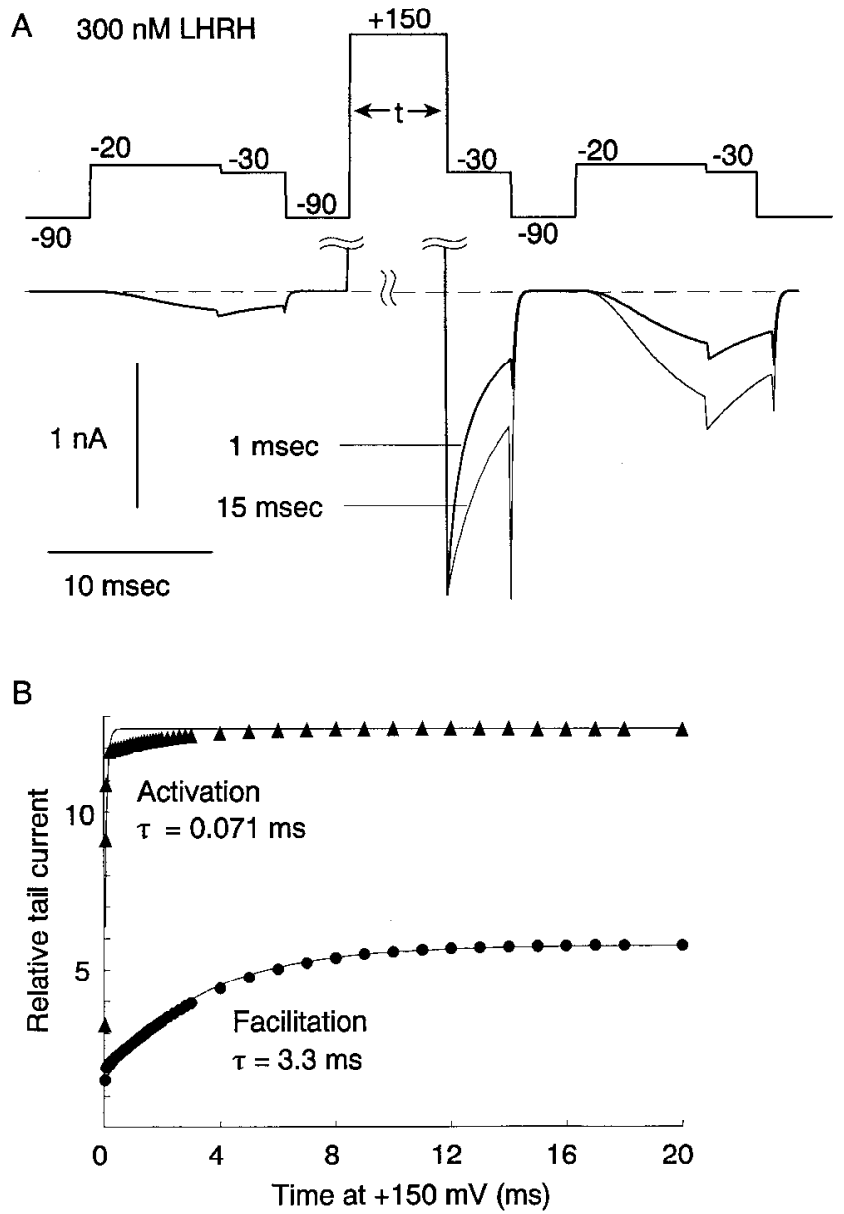

Figure 16. Simulation of facilitation and activation with the four G-protein model. Voltage protocol and analysis are as in the experiment of Figure 11.

binding of G-proteins during voltage pulses, since in such models the rate of G-protein binding would depend on G-protein concentration and thus the degree of modulation by transmitter. Constructing a model like that in Figure 13 shows the difficulty of making predictions without actual simulations. When an experiment like that of Kasai and Aosaki is simulated (Fig. 15B), the slow phase of activation actually becomes somewhat slower with more inhibition of the channel by increasing transmitter concentrations, contrary to the expectation that a faster rate of G-protein binding would lead to a shorter time constant of G-protein equilibration at higher transmitter concentrations. In the model, the time constant of slow activation is a complicated result of transitions between many states; although the rate constants for G-protein binding do get faster with higher transmitter concentrations, the distribution of channels early in a depolarization is shifted to favor states with more than one G-protein bound, which must undergo more unbinding steps to open. (In the model, it is not necessary for channels to unbind G-proteins in order to open, but for moderatc depolarizations like that to $0 \mathrm{mV}$ in Fig. $15 B$ the slow phase of activation does reflect mainly transitions involving unbinding of G-protein from states where some but not all channel gating subunits have activated.) The net result is moderate dependence on transmitter concentration in the opposite direction than might be expected from simple models, with the slow phase of activation being somewhat slower $(\tau=52 \mathrm{msec})$ at saturating transmitter concentrations than with the partial effects of $10 \mathrm{nM}(\tau=19 \mathrm{msec})$ or $30 \mathrm{nM}(\tau=26 \mathrm{msec})$ I.HRH.

The dependence of slow activation kinetics on G-protein concentration is complicated because both the initial conditions and rate constants change. More straightforward predictions can be made for the redevelopment of inhibition (or recovery from facilitation). Here, the initial conditions are nearly the same if a sufficiently long and strong depolarization is given to produce maximal facilitation, so the rate of recovery from facilitation should strongly reflect the concentration of G-proteins and become faster with greater effect of transmitter. Versions of this experiment have been performed by Kasai (1992) and Lopez and Brown (1991) with different results; Kasai found no difference in the reestablishment of inhibition with $10 \mathrm{nM}$ or $10 \mu \mathrm{M}$ enkephalin applied to NG108-15 cells, while Lopez and Brown rcportcd faster rcinhibition with morc G-protcin activation by higher GTP $\gamma$ S:GTP ratios. Based on their results, Lopez and Brown proposed that the reinhibition reflects binding of G-proteins to the channels, in agreement with the model in Figure 13.

The clearest distinctions between the general categories of models like that of Kasai (where altered kinetics reflect gating of channels continuously bound by G-protein) and that of Elmslie et al. (where facilitation and recovery from facilitation reflect unbinding and rebinding of G-proteins) come from comparisons of activation and facilitation for strong depolarizations. In the model of Kasai, facilitation reflects a slow gating step in modified channels that precedes channel activation, so that activation of channels cannot be faster than facilitation measured with a double-pulse protocol as in Figure 11. In contrast, in the models of Elmslie et al. and in Figure 13, facilitation requires the unbinding of G-protein, so it is a distinguishable process from channel opening, which can occur with G-protein still bound (with large enough depolarizations). In these models, unbinding of G-protein is not voltage dependent while the activation rate constants are highly voltage dependent. Thus, with large enough depolarizations, channel opening can be made very fast while facilitation should reach a limiting, slower time course. The prediction that activation should be faster than facilitation is borne out by the experimental observations in Figure 11, which seem impossible to reconcile with models in which the slower facilitating step precedes activation. The model in Figure 13 produces a reasonable simulation of the experimental results (Fig. 16). In the model, the time course of facilitation becomes faster with depolarization but reaches a limiting time constant of about $3.5 \mathrm{msec}$ for depolarizations positive to about $+50 \mathrm{mV}$. At voltages of less than $+50 \mathrm{mV}$ or so, the slower phase of channel opening (reflecting G-protein-bound channels) has virtually the same time course as the development of facilitation, but for very large depolarizations, as for the step to $+130 \mathrm{mV}$ in Figures 11 and 16, the opening rate of even G-protein-bound channels becomes very rapid due to the exponential dependence of activation rate constants on voltage, so that channels open maximally before there is time for G-proteins to unbind significantly.

The simulated currents in Figure 16A show that the model also accounts for the different kinetics of tail currents that follow short or long depolarizations to very positive potentials. Following short depolarizations, channels have opened but G-protein is still bound, so that the deactivation rate constants are accelerated. For longer depolarizations, G-protein has unbound so that the open channels are in the normal, unbound state and 
deactivate more slowly. Viewed in this light, the experimentally observed change in time course but not amplitude of tail currents as large depolarizations are made longer (Fig. 11) can be taken as evidence for the idea that G-protein-bound channels can open with large enough depolarizations (Bean, 1989; Elmslie et al., 1990).

\section{Application of transmitter during a depolarization}

A previous article reported that norepinephrine produced inhibition of $\mathrm{Ca}$ channel current in frog sensory neurons when applied during a long depolarization in a protocol like that in Figure 9 (Bean, 1989). Jones (1990) reported a similar experiment with salmon LHRH in a frog sympathetic ganglion neuron. These reports contrast with the results in Figure 9, where LHRH had little or no effect when applied during a depolarization to $-20 \mathrm{mV}$. As shown in Figure 17, the model in Figure 13 predicts much less inhibition if LHRH is applied during a depolarization than at the resting potential; this is because binding of G-proteins is weaker to channels that have one or more subunits in the activated state, as during the steady depolarization. The small degree of inhibition during the depolarization predicted by the model $(\sim 15 \%)$ is clearly greater than observed experimentally, although under the influence of the modeled results it is possible to vicw the experimental records (Fig. 9) as being consistent with a $5-10 \%$ inhibition. In fact, the predictions of the model are reminiscent of the small inhibition seen in the published records with application of norepinephrine (Bean, 1989), where inhibition develops and recovers quickly (faster than at resting potentials, because the much faster unbinding rate gives faster equilibration). This is puzzling, because norepinephrine generally produces smaller effects than LHRH when applied in conventional pulse protocols. An additional complication is that we have been unable to reproduce the result reported by Bean (1989) using norepinephrine applied to frog sympathetic or sensory neurons, even in cases where substantial inhibition could be seen with conventional protocols; Jones similarly reported his similar result with salmon LHRH to be difficult to reproduce (Jones, 1991, and personal communication). The inconsistency of the results with norepinephrine raises the possibility that the inhibition during a long pulse, when present, reflects a different pathway of modulation. This would fit with a distinction between effects of transmitters produced by a fast voltage-dependent pathway (which would not inhibit during a long depolarization) and a fast voltage-independent pathway (which would) proposed by Beech et al. (1992). In this connection, it may be significant that norepinephrine usually induces a much less prominent slow activation phase of $\mathrm{Ca}$ channel current than is seen with LHRH and some other transmitters.

\section{Limitations of the model}

The simulations show that many of the transmitter-induced changes in kinetics and voltage dependence of $\mathrm{Ca}$ channel currents can be explained by the hypothesis of state-dependent binding of $\mathrm{G}$-proteins. The model makes predictions that fit reasonably well with experimental observations on the shift in tail current activation curve, the changes in tail current kinetics, the slow phase of activation with voltage-dependent time constant, the different time courses of activation and facilitation, and the minimal effect of transmitter applied during a long depolarization.

The most obvious features of the experimental data not accounted for by the model are the presence of inhibition (by
A

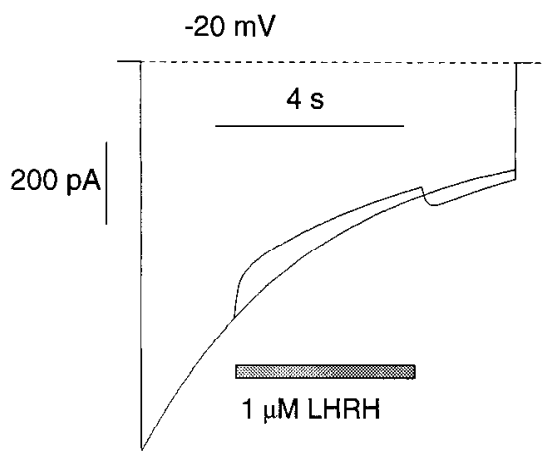

B

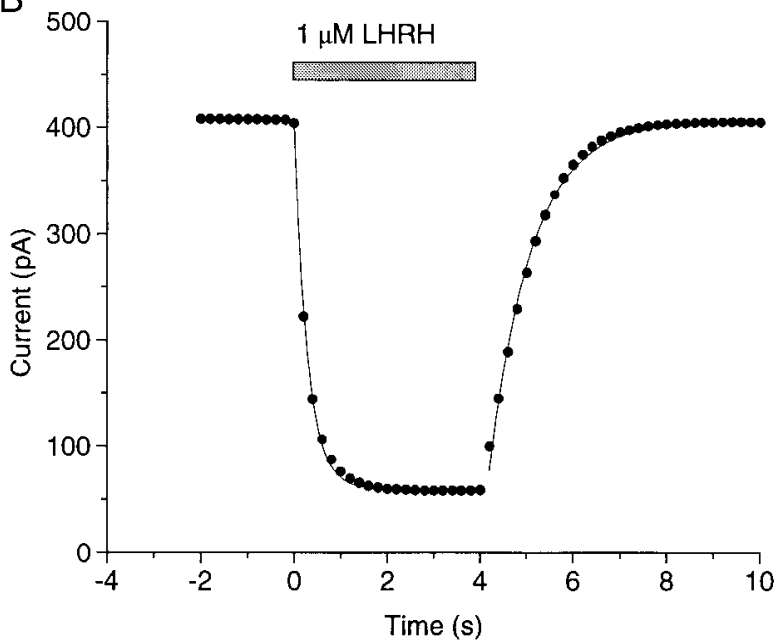

Figure 17. Simulation of state dependence of LHRH action using model in Figure 13. Simulations were done with LHRH applied during a long pulse to $-20 \mathrm{mV}(A)$ or at a holding potential of $-80 \mathrm{mV}$ using $5 \mathrm{msec}$ pulses to $-20 \mathrm{mV}$ (every $200 \mathrm{msec}$ ) to assay inhibition $(B)$. The time course of onset in $B$ is fit with a timc constant of $0.29 \mathrm{sec}$, and the time course of recovery is fit with a time constant of $0.91 \mathrm{sec}$.

$\sim 30 \%$ ) for very large depolarizations and the incomplete relaxation toward control levels during the slow activation phase. In these respects, the model is closer to experimental results with 2-chloroadenosine applied to chick DRG neurons (Kasai and Aosaki, 1989) or enkephalin applied to neuroblastoma cells (Kasai, 1992) than for LHRH on sympathetic neurons.

The mechanism of inactivation in the model (proceeding with a voltage-independent rate only from the open state) is too simple to account for the inactivation properties actually observed with $\mathrm{N}$-type channels. Since inactivation proceeds only from the open state in the model, it is incapable of accounting for the inactivation that is seen experimentally for $3 \mathrm{sec}$ prepulses to potentials below $-40 \mathrm{mV}$, where there is negligible channel opening. Simulations with the model (not shown) yielded a much steeper inactivation curve than that seen experimentally (Fig. 10). Most likely, real N-type channels can also inactivate from closed states, as in some models of sodium channels (Vandenberg and Bezanilla, 1991).

The model does not include delays arising from LHRH binding and unbinding from its receptor. In the simulation in Figure 17 the concentration of activated G-protein is assumed to rise and fall instantaneously with application and removal of LHRH. The model predicts faster onset $(\tau=290 \mathrm{msec})$ and offset $(\tau=$ $910 \mathrm{msec}$ ) with jumps in $\mathrm{G}$-protein than seen experimentally with jumps in LHRH concentration $\left(\tau_{\text {on }} \sim 2 \mathrm{sec}, \tau_{\text {off }} \sim 19 \mathrm{sec}\right)$. 
It seems likely that the onset and offset kinetics might be limited by the rate of formation and decline of activated G-proteins, not binding and unbinding. There are other issues-localization of $\mathrm{G}$-proteins, how big a pool of $\mathrm{G}$-proteins is seen by a single channel, whether G-proteins are freely diffusible-that are not considered in the model. For example, the law of mass action would not be applicable if recovery from facilitation is mostly due to rebinding of the same G-protein just released from the channel during a depolarization (as might happen if the proteins do not diffuse away from each other quickly); in this case, the rate of recovery might not be dependent on the number of activated $\mathrm{G}$-proteins available (cf. Lopez and Brown, 1991; Kasai, 1992), at least not in a simple way.

\section{Comparison with single-channel information}

Implicit in the interpretation of our experiments is the idea that LHRH influences the gating of N-type channels but not singlechannel current. This idea is supported by previous recordings from bullfrog sympathetic neurons by Lipscombe et al. (1989), who found that norepinephrine, which has generally similar effects as LHRH (Bley and Tsien 1990), reduces $\mathrm{N}$-channel activity without altering single-channel current. The main effect of norepinephrine in their experiments was to reduce open probability by accelerating channel closing, with a possible additional slowing of channel opening. In a general way, these effects fit well with the idea incorporated into Figure 13 that G-protein binding destabilizes activated states of the channel. However, the kinetic scheme used in Figure 13 posits a final opening step that is not voltage dependent and is not affected by G-protein binding, so channel activity would have the same open times under all conditions of $\mathrm{G}$-protein binding. The assumption of a final voltage-independent opening step is not crucial for the model; it was adopted for consistency with better-characterized gating of $\mathrm{K}$ channels, but there is little direct evidence on this point for N-type Ca channels.

Recent data from two groups have distinguished different "modes" of N-type channel gating under control conditions. Rittenhouse et al. (1991) find two distinct patterns of singlechannel activity in rat sympathetic neurons, characterized by low and high open probability. Delcour et al. (1991, 1992), distinguish three modes of gating in bullfrog sympathetic neurons, with low, medium, and high open probabilities. It is tempting to suppose that these might correspond to channels with 0 (high probability), 1 (medium probability), or more (low probability) G-proteins bound. Consistent with this interpretation, the different modes of single-channel activity have different voltage dependencies, with high, medium, and low probability modes having activation midpoints of $-13 \mathrm{mV},-3 \mathrm{mV}$, and $+31 \mathrm{mV}$. However, a number of quantitative comparisons do not fit neatly with such a correspondence. Unlike the observations of Ikeda (1991) in rat sympathetic neurons, we find little facilitation $(<10 \%)$ under control conditions, suggesting that the representation of G-protein-bound channels would be minimal in the unstimulated cells used by Delcour et al. Moreover, the rate constant for unbinding of $\mathrm{G}$-protein used in the model (1.2 sec $\left.{ }^{1}\right)$ would predict average sojourns in the G-protein-bound modes of only about $1 \mathrm{sec}$, not the $10 \mathrm{sec}$ observed by Delcour et al. Also, an identification of high, medium, and low probability modes with an increasing number of bound $\mathrm{G}$-proteins would predict that there would not be direct transitions between high and low probability modes, although such transitions were observed (in both directions) by Delcour et al.
Detailed quantitative comparisons between the two sets of observations may be hard to interpret because of different recording conditions (high vs low external $\mathrm{Ba}$, dialyzed vs intact cell, acutely isolated vs cultured cells). There is a powerful prediction of the model in Figure 13 that is less dependent on quantitative comparisons: strong depolarizations should be able to convert channels from a low to a high probability mode, by causing unbinding of G-protein. It would be interesting to test the effect of a $10-20 \mathrm{msec}$ depolarization to $+130 \mathrm{mV}$ or so delivered during a run of low probability sweeps.

\section{References}

Anwyl R (1991) Modulation of vertebrate neuronal calcium channels by transmitters. Brain Res Rev 16:265-281.

Bean BP (1989) Neurotransmitter inhibition of neuronal calcium currents by changes in channel voltage dependence. Nature 340: 153-156.

Bean BP, Nowycky MC, Tsien RW (1984) B-adrenergic modulation of calcium channels in frog ventricular heart cells. Nature 307:371-375.

Beech DJ, Bernheim L, Hille B (1992) Pertussis toxin and voltage dependence distinguish multiple pathways modulating calcium channels of rat sympathetic neurons. Neuron 8:97-106.

Bernheim L, Beech DJ, Hille B (1991a) A diffusable second messenger mediates one of the pathways coupling receptors to calcium channels in rat sympathetic neurons. Neuron 6:859-867.

Bernheim L, Mathie A, Hille B (1991b) Muscarinic modulation of Nand L-type calcium channels in rat sympathetic neurons. Soc Neurosci Ahstr 17:61.

Bley KR, Tsien RW (1990) Inhibition of $\mathrm{Ca}^{2+}$ and $\mathrm{K}^{+}$channels in sympathetic neurons by neuropeptides and other ganglionic transmitters. Neuron 2:379-391.

Bosma MM, Hille B (1989) Protein kinase C is not necessary for peptide-induced suppression of M-current or for desensitization of the peptide receptors. Proc Natl Acad Sci USA 86:2943-2947.

Breitwieser G, Szabo G (1988) Mechanism of muscarinic receptorinduced $\mathrm{K}^{+}$channel activation as revealed by hydrolysis-resistant GIP analogs. J Gen Physiol 91:469-493.

Brown AM, Birnbaumer L (1988) Direct G-protein gating of ion channels. Am J Physiol 23:H401-H410.

Delcour AH, Lipscombe D, Tsien RW (1991) Multiple gating modes and noradrenergic modulation of N-type $\mathrm{Ca}^{2+}$ channels in frog sympathetic neurons. Soc Neurosci Abstr 17:900.

Delcour AH, Lipscombe D, Tsien RW (1992) Three modes of N-type channel activity distinguished by differences in gating kinetics. J Neurosci, in press.

Deisz DA, Lux HD (1985) $\gamma$-Aminobutyric acid induced depression of calcium currents of chick sensory neurons. Neurosci Lett 56: 205-210.

Dolphin AC, Scott RH (1987) Calcium channel currents and their inhibition by ( - )-baclofen in rat sensory neurones: modulation by guanine nucleotide. J Physiol (Lond) 386:1-17.

Elmslie KS, Zhou W, Jones SW (1990) LHRH and GTP $\gamma$ S modify calcium current activation in bullfrog sympathetic neurons. Neuron $5: 75-80$.

Ewald DA, Sternweis PC, Miller RJ (1988) Guanine nucleotide-binding protein Go-induced coupling of neuropeptide $\mathrm{Y}$ receptors to $\mathrm{Ca}^{2+}$ channels in sensory neurons. Proc Natl Acad Sci USA 85:3633-3637.

Fisher R, Johnston D (1990) Differential modulation of single voltage gated calcium channels by cholinergic and adrenergic agonists in adult hippocampal neurons. J Neurophysiol 64:1291-1302.

Forscher P, Oxford GS (1985) Modulation of calcium channels by norepinephrine in internally dialyzed avian sensory neurons. J Gen Physiol 85:743-763.

Friel DD, Bean BP (1988) Two ATP-activated conductances in bullfrog atrial cells. J Gen Physiol 91:1-27.

Green KA, Cottrell GA (1988) Actions of baclofen on components of the Ca-current in rat and mouse DRG neurones in culture. $\mathrm{Br} \mathrm{J}$ Pharmacol 94:235-245.

Gross RA, MacDonald RL (1987) Dynorphin A selectively reduces a large transient (N-type) calcium current of mouse dorsal root ganglion neurons in cell culture. Proc Natl Acad Sci USA 84:5469-5473.

Hamill OP, Marty A, Neher E, Sakmann B, Sigworth FJ (1981) Im- 
proved patch-clamp techniques for high-resolution current recording from cells and cell-free membrane patches. Pfluegers Arch 391:85-100. Harris-Warwick RM, Hammond C, Paupardin-Tritsch D, Homburger V, Rouot B, Bockaert J, Gerschenfeld HM (1988) An $\alpha_{40}$ subunit of a GTP-binding protein immunologically related to $G_{0}$ mediates a dopamine-induced decrease of $\mathrm{Ca}^{2+}$ current in snail neurons. Neuron $1: 27-32$.

Hescheler J, Rosenthal W, Trautwein W, Schulz G (1987) The GTPbinding protein $G_{0}$ regulates neuronal calcium channels. Nature 325 : 445-447.

Hess P, Lansman JB, Tsien RW (1984) Different modes of gating behavior favored by dihydropyridine $\mathrm{Ca}$ agonists and antagonists. Nature 311:538-544.

Holz GG, Rane SG, Dunlap K (1986) GTP-binding proteins mediate transmitter inhibition of voltage-dependent calcium channels. Nature 319:670-672.

Humphries J, Wan Y-P, Folkers K (1978) Inhibitory analogues of the luteinizing hormone-releasing hormone having $\mathrm{D}$-aromatic residues in positions 2 and 6 and variation in position 3. J Med Chem 21: $120-123$

Ikeda SR (1991) Double-pulse calcium current facilitation in adult rat sympathetic neurones. J Physiol (Lond) 439:181-214.

Ikeda SR, Schofield GG (1989) Somatostatin blocks a calcium current in rat sympathetic ganglion neurones. J Physiol (Lond) 409:221-240.

Jones SW (1990) Time course of neurotransmitter effects on voltagedependent currents of bullfrog sympathetic neurons. Soc Neurosci Abstr 16:623.

Jones SW (1991) Time course of receptor-channel coupling in frog sympathetic neurons. Biophys J 60:502-507.

Jones SW, Jacobs LS (1990) Dihydropyridine actions on calcium currents of frog sympathetic neurons. J Neurosci 10:2261-2267.

Jones SW, Marks TN (1989) Calcium currents in bullfrog sympathetic neurons. I. Activation kinetics and pharmacology. J Gen Physiol 94: 151-167.

Kasai H (1992) Voltage- and time-dependent inhibition of neuronal calcium channels by a GTP-binding protein in a mammalian cell line. J Physiol (Lond) 448:189-200.

Kasai H, Aosaki T (1989) Modulation of Ca-channel current by an adenosinc analog mediatcd by a GTP-binding protein in chick sensory neurons. Pfluegers Arch 414:145-149.

King JA, Davidson JS, Millar RP (1988) Interaction of endogenous chicken gonadotrophin-releasing hormone-I and -II on chicken pituitary cells. J Endocrinol 117:43-49.

Koren G, Liman ER, Logothetis DE, Nadal-Ginard B, Hess P (1990) Gating mechanism of a cloned potassium channel expressed in frog oocytes and mammalian cells. Neuron 2:39-51.

Lewis DL, Weight FF, Luini A (1986) A guanine nucleotide-binding protein mediates the inhibition of voltage-dependent calcium current by somatostatin in a pituitary cell line. Proc Natl Acad Sci USA 83: 9035-9039.

Lipscombe D, Kongsamut S, Tsien RW (1989) $\alpha$-Adrenergic inhibition of sympathetic neurotransmitter release mediated by modulation of N-type calcium-channel gating. Nature 340:639-642.

Lopez HS, Brown AM (1991) Correlation between G protein activation and reblocking kinetics of $\mathrm{Ca}^{2+}$ channel currents in rat sensory neurons. Neuron 7:1061-1068.

Maguire G, Maple B, Lukasiewicz P, Werblin F (1989) $\gamma$-Aminobutyric type $B$ receptor modulation of L-type calcium current at bipolar cell terminals in the retina of the tiger salamander. Proc Natl Acad Sci USA 86:10144-10147.

Marchetti C, Carbone E, Lux HD (1986) Effects of dopamine and noradrenaline on $\mathrm{Ca}^{2+}$ channels of cultured sensory and sympathetic neurons of chick. Pfluegers Arch 406:104-111.
McFadzean I, Mullaney I, Brown DA, Milligan G (1989) Antibodies to the GTP binding protein, $G_{0}$, antagonize noradrenaline-induced calcium current inhibition in NG108-15 hybrid cells. Neuron $3: 177-182$.

Nowycky MC, Fox AP, Tsien RW (1985) Long-opening mode of gating of neuronal calcium channels and its promotion by the dihydropyridine calcium agonist Bay K 8644. Proc Natl Acad Sci USA 82: 2178-2182

Penington NJ, Kelly JS, Fox AP (1991) A study of the mechanism of $\mathrm{Ca}^{2+}$ current inhibition produced by serotonin in rat dorsal raphe neurons. J Neurosci 11:3594-3609.

Pfaffinger $P$ (1988) Muscarine and t-LHRH suppress M-current by activating an IAP-sensitive G-protein. J Neurosci 8:3343-3353.

Plummer MR, Logothetis DE, Hess P (1989) Elementary properties and modulation of calcium channels in mammalian peripheral neurons. Neuron 2:1453-1463.

Plummer MR, Rittenhouse A, Kanevsky M, Hess P (1991) Neurotransmitter modulation of calcium channels in rat sympathetic neurons. J Neurosci 11:2339-2348.

Pollo A, Taglialatella M, Carbone E (1991) Voltage-dependent inhibition and facilitation of $\mathrm{Ca}$ channel activation by GTP- $\gamma-\mathrm{S}$ and $\mathrm{Ca}$ agonists in adult rat sensory neurons. Neurosci Lett 123:203-207.

Regan LJ, Sah DWY, Bean BP (1991) $\mathrm{Ca}^{2+}$ channels in rat central and peripheral neurons: high-threshold current resistant to dihydropyridine blockers and $\omega$-conotoxin. Neuron 6:269-280.

Rittenhouse AR, Plummer MR, Hess P (1991) Microscopic heterogeneity of N-type calcium channel gating. Soc Neurosci Abstr 17:901.

Sah DWY (1990) Neurotransmitter modulation of calcium current in rat spinal cord neurons. J Neurosci 10:136-141.

Schofield GG, Ikeda SR (1988) Neuropeptide Y blocks a calcium current in C cells of bullfrog sympathetic ganglia. Eur J Pharmacol 151:131-134.

Song S-Y, Saito K, Noguchi K, Konishi S (1989) Different GTPbinding proteins mediate regulation of calcium channels by acetylcholine and noradrenaline in rat sympathetic neurons. Brain Res 494: 383-386

Toselli M, Lux HD (1989) GTP-binding proteins mediate acetylcholine inhibition of voltage-dependent calcium channels in hippocampal neurons. Pfluegers Arch 413:319-321.

Toselli M, Lang J, Costa T, Lux HD (1989) Direct modulation of voltage-dependent calcium channels by muscarinic activation of a pertussis-toxin-sensitive G-protein in hippocampal neurons. Pfluegers Arch 415:255-261.

Tse A, Clark RB, Giles WR (1990) Muscarinic modulation of calcium current in neurones from the interatrial septum of bull-frog heart. $J$ Physiol (Lond) 427:127-149.

Tsunoo A, Mitsunobu Y, Narahashi T (1986) Block of calcium channels by enkephalin and somatostatin in neuroblastoma-glioma hybrid NG108-15 cells. Proc Natl Acad Sci USA 83:9832-9836.

Vandenberg CA, Bezanilla F (1991) A sodium channel gating model based on single channel, macroscopic ionic, and gating currents in the squid giant axon. Biophys $\mathbf{J}$ 60:1511-1533.

Wanke E, Ferroni A, Malgaroli A, Ambrosini A, Pozzan T, Meldolesi J (1987) Activation of a muscarinic receptor selectively inhibits a rapidly inactivated $\mathrm{Ca}^{2+}$ current in rat sympathetic neurons. Proc Natl Acad Sci USA 84:4313-4317.

Yatani A, Brown AM (1989) Rapid $\beta$-adrenergic modulation of cardiac calcium channel currents by a fast G-protein pathway. Science 245:71-74.

Zagotta WN, Aldrich RW (1990) Voltage-dependent gating of Shaker A-type potassium channels in Drosophila muscle. J Gen Physiol 95: 29-60. 